\title{
Bank accounting conservatism and bank loan quality
}

\begin{abstract}
This study examines the effect of conservatism on bank's own monitoring effort reflected in its loan portfolio quality. While prior research shows that timely recognition of expected loan losses reduces managerial risk taking through enhanced market discipline, few are the studies that investigate the implication of asymmetric timeliness of losses, otherwise known as conservatism, on bank risk taking or a bank's own monitoring effort. Building on the premise that the monitoring benefit of conservatism in reducing bank's risk-taking translates into better loan portfolio quality, this study documents that in a sample of publicly traded bank holding companies in the United States over the period 1994-2014, bank's conservatism is positively associated with loan quality. I also find that the effect of conservatism on loan quality is more pronounced for banks with high ex-ante information asymmetry or distress risk and during the low and high lending growth cycles when loan quality is likely to deteriorate. These findings should be of interest to regulators and policymakers who debate ways to incentivize banks to use their discretion inherent in loan loss provisioning in ways that is more informative and less opportunistic.
\end{abstract}

Keywords: Banks, Conservatism, Loan Quality, Information asymmetry, Transparency, Lending behavior

JEL codes: G21, M41 


\section{Introduction}

This study examines the relation between conservatism and loan quality for a sample of public banks in the US. While there is some evidence indicating that timely recognition of expected loan losses serves as a monitoring mechanism (Beatty and Liao, 2011; Bushman and Williams 2012, 2015), few are the studies that investigate the implication of asymmetric timeliness of losses, otherwise known as conservatism, on bank risk taking or a bank's own monitoring effort. This study attempts to fill this gap and takes a more direct approach by focusing on banks' primary operational decisions - that is, making loans. The study builds on the premise that the monitoring benefit of conservatism in reducing bank's risk-taking translates into better loan portfolio quality. By establishing a formal connection between conservatism and loan quality, this research complements and extends the literature on the benefits of bank reporting transparency.

An emerging stream of research has viewed timely recognition of expected loan losses as desirable to curtail excessive risk-taking by banks (Bushman and Williams, 2012, 2015). While GAAP traditionally requires an "incurred loss" methodology for recognizing credit losses that delays recognition until it is probable a loss has been incurred, the complexity of loan portfolios allows substantial discretion in provisioning (Dugan, 2009). ${ }^{1}$ Banks' delayed provisioning for expected loan losses can mask true risk of loan portfolios, and thus can deteriorate bank

\footnotetext{
${ }^{1}$ On June, 2016, the FASB issued ASU No. 2016-13, Financial Instruments-Credit Losses (Topic 326) which requires banks immediately record the full amount of credit losses that are expected in their loan portfolios, providing investors with better information about those losses on a timelier basis. GAAP traditionally requires an "incurred loss" methodology for recognizing credit losses that delays recognition until it is probable a loss has been incurred. This model has been criticized as the recognition of loan losses is delayed until borrowers actually default and magnify pro-cyclicality of loan making. The new credit loss standard allows managers to incorporate estimates of potential future events, and therefore affords managers considerably more discretion than does the incurred loss model.
} 
transparency. Because provision is made against expected loan losses, and bank capital is set aside to buffer against unexpected loan loses, less timelier provisioning may obscure true ability of bank capital to provide buffer against unexpected losses by forcing the expected loan losses to be absorbed by bank capital in the future. Consequently, most banking literature focuses on how banks exercise discretion in loan loss provisioning to understand the implication of timely loan loss recognition in banks. For example, less timely recognition of loan losses reduces banks' willingness to lend which increases pro-cyclicality during crisis periods (Beatty and Liao 2011), increases risk shifting and illiquidity in the economy (Bushman and Williams 2012), increases equity price crash risks (Andreou et al. 2017), increases lending corruption (Akins, Dou, and Ng 2017), and exposes banks to systematic downside risk (Bushman and Williams 2015).

Notably, while most research focuses on the timeliness of recognition of loan losses, less attention is given to the asymmetric timeliness of loss recognition versus gains. Asymmetric timeliness is a different aspect of financial reporting from timelines in that asymmetric timeliness focuses on the relative timing of bad news release to good news while timeliness does not distinguish good news timeliness from bad news timeliness. Asymmetric timeliness is uniquely designed to provide contracting benefits by counteracting managerial tendency to disclose good news rather than bad news quickly. The fact that losses need to be reported sooner than gains effectively disciplines managers to engage in optimal investments and triggers early abandonment of poorly performing projects. Prior studies find evidence suggesting that asymmetric timely loan loss recognition, otherwise known as conditional conservatism, facilitates the efficient allocation of capital in the form of improved investment decisions. This is because it reduces information asymmetry which reduces financing friction and managerial opportunism by enhancing market disciplining of firms' risk-taking decisions. Many recent 
studies support this prediction (e.g., García Lara et al. 2016). However, relatively little attention is given to the benefits of conservatism in the banking industry.

Studying the implication of conservatism in the bank setting is important because conservative reporting is particularly desirable for banks for the following reasons. First, debt contracting is the primary explanation for why conservatism arises in financial reporting (Watts, 2003). Since banks are highly leveraged institutions, banks are expected to exhibit higher levels of conditional conservatism due to contracting demands, litigation costs and regulators' preference (Watts 2003; Armstrong et al., 2010).

Second, under more conservative accounting, managers report economic losses in a timelier manner, which counteracts managerial desire to report only good news and hide bad news and consequently facilitates informational transparency. Because banks are characterized as having greater information asymmetry and complex structure, conservatism, by requiring the timely disclosure of bad news, can be particularly helpful for banks (Flannery et al., 2013; Leventis et al.,2013; Levine, 2004). Central bankers prefer banks to exercise conservative accounting practices during economic upturns (Leventis et al., 2013; Turner, 2010).

Given that banks are expected to exhibit high levels of conservatism, and that they are also in a position to gain substantial benefits from conservative reporting, it is important to examine the implication bank reporting conservatism on bank's risk taking or banks' own monitoring effort.

In addition to investigating the overall effect of conservatism on loan quality, I introduce two conditional hypotheses. First, more conservatism is likely more desirable in mitigating risktaking incentives for banks when they have greater incentive to take more risks. Thus, drawing 
on prior research showing that incentives to risk shift is higher for firms with high information asymmetry or distress risk, this study further examines whether the improvement in loan quality is more sensitive to conservatism when these banks have high information asymmetry or experience greater distress. Second, this study considers the role of credit cycles, as prior studies document that loan quality is highly sensitive to credit cycles. More specifically, this study examine whether the impact of conservatism on loan quality will be more pronounced for the times when the average loan quality deteriorates, that is, during the times of extreme lending growth cycles. In low lending growth cycle, banks face higher adverse selection costs because there is higher likelihood of unknown borrowers having been rejected by another lender. In high lending growth cycle, as the perceived benefits of monitoring diminishes, banks may be tempted to reduce their monitoring and screening activities. Furthermore, as bank managers have the incentive to cater to this high demand through excessive lending (Berger and Udell, 2004; Foos et al., 2010), the quality of loan portfolios will deteriorate in high lending growth cycle.

To capture the degree of conditional accounting conservatism among banks, I use the Khan and Watts (2009) C-Score measure of timeliness of loss recognition for our main tests as well as the $C$-Score's decomposition into $C$-Score associated with loan loss provision and $C$ Score associated with earnings before provisions. Additionally, I develop another conservatism measure, loan loss provision asymmetry ( $\left.L L P \_A S Y\right)$, by modifying measures of timely recognition of expected loan losses employed by Beatty and Liao (2011) who estimate the equation where loan loss provisions are regressed on lagged (previous 2 quarters), contemporaneous, and future changes (1 quarter ahead) in NPLs along with capital and earnings before provisions. In the spirit of Basu (1997)'s piece-wise linear regression model, I similarly modify Beatty and Liao (2011)'s model by decomposing the changes in NPLs into increase in 
NPLs (=bad news) and decrease in NPLs (=good news). Then, I take the average of coefficients on increases in NPLs in the past, current, and future to capture the extent to which loss provision reflects asymmetric timeliness of bad news relative to good news reflected in NPLs.

The main results can be summarized as follows: Banks with greater conservatism (i.e. banks that recognize loan losses in a timelier fashion) are likely to have higher quality loan portfolios, the output of good monitoring over loan making decisions. A positive association between conservatism and loan quality is more pronounced for banks with high information asymmetry, or high financial distress. Moreover, the positive impact of conservatism on loan quality is more pronounced during the recessionary period (low credit cycle) as well as the expansionary period (high credit cycle) compared to the normal times because both the degree of information asymmetry and uncertainty about the quality of banks' loan portfolios increase and consequently loan quality deteriorates during those times.

A number of additional tests are conducted to examine the robustness of the primary findings. First, I find that the effect of conservatism on loan portfolio quality holds across all size groups. Second, I estimate the baseline regression in first-differences where change in loan quality is regressed on change in conservatism and change in control variables (change from to $t+1)$ to mitigate the effect of bank-specific characteristics that are relatively constant over time. The results are robust to this specification. Third, the results hold to alternative measures of monitoring quality such as Z-Score and salary expense as a dependent variable. Lastly, the results hold for both poor and strong corporate governance subsamples.

This study provides direct evidence on how conservatism affects banks' lending quality, which reflect banks' own monitoring efforts. While the prior studies (Bushman and Williams, 
2012; Bushman and Williams, 2015) look at the link between conservatism and risk profiles of banks, they mostly focus on systemic economy-wide risks or the market perception captured by stock behaviors using measures such as stock market illiquidity risk or the value-at-risk (Bushman and Williams, 2015), which is an indirect indicator for banks' own risk taking. Furthermore, given that loan performance is closely linked to financial stability, this study contributes to the discussion of financial stability in the light of the recent financial crisis by highlighting the role of bank financial reporting quality.

The remainder of the paper is organized as follows. Section 2 presents the background and hypotheses development. Section 3 introduces the research methodology. Section 4 introduces the data and descriptive statistics. Section 5 covers the empirical analyses on bank monitoring efforts and financial reporting quality. Section 6 details some additional analyses, and Section 7 concludes.

\section{Background and Hypotheses}

The banking literature posits that informational transparency plays a fundamental role in enhancing market discipline and prudential bank regulation. ${ }^{2}$ Market discipline is referred to as a process by which market participants monitor and discipline excessive risk taking by banks. For example, bank creditors can exert market discipline by withdrawing their funds, or demanding higher interest rates from riskier banks. For publicly traded banks, equityholders can exert some discipline by replacing management or by rationing their capital or demanding higher premium

\footnotetext{
${ }^{2}$ There are two types of information asymmetry banks face. One is information asymmetry between borrowers and depositors, while other is the one between insiders (e.g., managers, loan officers) and outsiders (e.g., capital providers, regulators). This study intends to focus on the role of financial reporting quality on the latter type of information asymmetry between insiders and outsiders.
} 
on their investments. The key that allows effective market discipline is how reliable and timely the banks provide information regarding their risk exposure and performance (Stephanou, 2010).

The role of reporting transparency is important, especially since the lack of transparency in financial institutions played a major role in the 2007-09 financial crisis by impairing bank supervisors' and market participants' understanding of bank risk (Acharya and Richardson, 2009). Because banks are more opaque due to their inherent complexity of a business and the nature of the underlying assets (Morgan, 2002), transparent information is essential for the investors to monitor the banking industry. If banks choose to withhold information from investors, or disclose information that is not credible, they are opaque (Bushman, 2016). Additionally, banks are highly leveraged, and thus may exhibit greater conservatism because conservatism tends to enhance debt contracting efficiency (Watts 2003). More conservatism can reduce investor uncertainty about banks' intrinsic value, strengthen market discipline over risktaking behavior, and provide disincentives for banks to suppress negative information that can engender capital inadequacy concerns. In this sense, conservatism is an important aspect of bank transparency because it reduces the managerial temptation to hide bad news by imposing timely recognition of expected loan losses.

Prior studies find evidence suggesting that conservatism improves financial transparency. For example, Andreou et al. (2017) find that banks having lower conservatism are more likely to experience significant drops in equity values. Akins, Dou, and $\mathrm{Ng}$ (2017) find evidence that conservaitsm constrains lending corruption measured by the survey response of borrowers. Manganaris, Beccalli, and Dimitropoulos (2017) find the increased conservatism after the financial crisis among European listed banks, which is interpreted as banks' attempt to increase transparency to alleviate the adverse consequences of the opaqueness. 
Among the multiple benefits of conservatism, the most relevant to this study is the ability of conservatism to reduce managerial risk shifting behavior. A risk shifting problem is defined as a phenomenon where shareholders of firms with outstanding risky debt may benefit from increasing the risk of the firm (Jensen and Meckling, 1976). Risk shifting is a more severe problem in banks than in other industrial firms, because (1) debt financing represents the predominant source of external funding for banks (Freixas and Rochet, 2008), (2) it is relatively easy for banks to alter financial risks without being immediately noticed by creditors (Myers and Rajan, 1998), and (3) there are implicit and explicit public guarantees for debts (Battacharya and Thakor, 1993).

Conservatism can prevent banks from taking excessive risk because it helps design an effective incentive contract for managers, assess and reward managerial performance more effectively in the presence of asymmetric information and payoffs (Bushman and Smith, 2001; Armstrong, Guay, and Weber, 2010). Riskier investments would subject firms to greater potential losses or gains. Under conservative accounting, losses need to be reflected in earnings sooner and in a complete manner, while gains are reported gradually over time. Thus, riskier investments can result in losses being reported in earnings in the short-term without a corresponding increase in the probability of reporting a larger gains in the short term. This implies that conservatism can decrease managerial incentives to make risky investments. Consistently, Kravet (2014) finds that under more conservative accounting managers make less risky acquisitions and that firms with accounting-based debt covenants drive this association. Similarly, in banks, managers are deterred to extend loans to riskier borrowers under conservative accounting. Bushman and Williams (2012) evaluate the impact of conservatism 
on the risk shifting behavior of banks and find that forward-looking provisions designed to reflect expected loan losses more timely is associated with increased discipline.

Because conservatism improves investment efficiency by limiting managerial risk taking incentives, I expect conservatism can promote more prudent loan portfolio selection and deter managers from continuing or increasing loans to default-prone borrowers, resulting in lower default risks in the loan portfolio of the bank. Without conservatism, managers of banks with deteriorating loans have incentives to postpone revealing this to the market by increasing loan volume, which generates profitable upfront fees and boosts earnings despite the fact that these loans would ultimately result in negative net income. When conservatism is required, future anticipated losses need to be fully reflected in loan loss provision, reducing profit and capital levels on which manager's compensation is based.

Based on the above discussion, I hypothesize that, ceteris paribus, conservatism disciplines banks' risk-taking over lending practices, leading to higher quality loan portfolios. The first hypothesis is formally stated as below:

Hypothesis 1: More conservative banks have better loan quality.

The relative importance of conservatism in monitoring investment decisions likely varies with a firm's ex ante risk-shifting incentive. I consider two settings where ex ante risk-taking incentive is likely to be high: banks with greater inherent information asymmetry and banks with in greater distress risk.

The greater information asymmetry between banks and outside capital providers, the more uncertainty on the value of a borrower's assets. In turn, the true value of a borrower as well as that of loan portfolios is largely unknown, which results in greater agency costs for bank 
stakeholders. Timely recognition of loan losses can directly help inform investors or depositors of banks' true value (e.g., the value of loan portfolios) because the book value of a bank that recognize losses on a timelier basis provides a lower-bound estimate for the bank's orderly liquidation value. Information asymmetry exacerbates risk-taking problems because greater information asymmetry hinders market monitoring, monitoring by boards of directors and regulators, implying greater potential for moral hazard and adverse selection problems (Jensen, and Meckling 1976). Therefore, managers in these firms have greater latitude to indulge their own preferences, such as consuming excessive perks or taking excessive risk. Information asymmetry can also exacerbate the financing frictions imposed on banks seeking to raise capital in response to negative balance sheet shocks (Beatty and Liao 2011; Bushman and Williams 2015), which can adversely affect incentives of bank managers and lead them to make inefficient investment decisions (Goldstein and Sapra 2014).

Prior studies suggest that the demand for conservatism arises from information asymmetry, and firms can gain more benefit from conditional conservatism when they have greater information asymmetry. For example, LaFond and Watts (2008) find that information asymmetry between shareholders and managers leads to more conservatism and the implementation of accounting conservatism reduces information asymmetry. Consistent with this, Nichols et al. (2009) find that conservatism is more pronounced in public banks compared to private banks because the demand for conservatism increases with greater information asymmetry. Francis and Martin (2010) document that the positive association between timely loss recognition and acquisition profitability is more pronounced for firms with higher ex ante information asymmetry. Garcia Lara et al. (2016) find that the ability of conservatism to reduce investment inefficiency is greater for firms having greater information asymmetry. Conservatism 
are thus likely to play an even more prominent role in reducing managers' incentives to make unprofitable and overly risky investment decisions or delay project abandonment decisions. These arguments lead to the second hypothesis.

$\mathrm{H} 2 \mathrm{~A}$ : The positive association between conservatism and asset quality is more pronounced for banks with high information asymmetry.

Jensen and Meckling (1976) offer a risk-shifting hypothesis in which managers of financially distressed firms maximize the limited liability option of shareholders by investing in a risky projects offering improbable high pay-offs at the expense of debtholders. Distressed banks are more likely to violate regulatory capital requirements and are poorly performing. Thus, banks could be motivated to use the discretion inherent in the loan loss provisioning to avoid violation of regulatory capital constraints. Following Bushman and Williams (2012) who find that the benefits of forward-looking provisioning in reducing risk-shifting problems are more pronounced in the subset of banks with low balance sheet capital or low return-on-equity (ROE), I test whether the effects of conservatism on loan quality are more pronounced for high-distress banks by using similar proxies to measure bank distress risk.

$\mathrm{H} 2 \mathrm{~B}$ : The positive association between conservatism and asset quality is more pronounced for banks with high financial distress.

Prior studies document that loan quality is highly sensitive to credit cycles. More specifically, this study examine whether the impact of conservatism on loan quality will be more pronounced for the times when the average loan quality deteriorates, that is, during the times of extreme lending growth cycles. 
For example, during the low lending cycle (credit crunch), banks face higher adverse selection costs because there is higher likelihood of unknown borrowers having been rejected by another lender (Dell'Ariccia and Marquez, 2006). During the high lending growth cycle which coincides with the economic boom, the default probability of average loans decrease as firms have a higher probability of having positive NPV projects to pursue. In turn, during the high lending cycle, banks may be tempted to reduce their monitoring and screening activities because the perceived benefits of monitoring effort are diminished. Furthermore, as bank managers have the incentive to cater to this high demand through excessive lending (Berger and Udell, 2004; Foos et al., 2010), the quality of loan portfolios will deteriorate. Consistent with this, Andreou et al. (2017) find that conservatism reduces the abrupt stock price crash risks particularly during the low and high-lending growth cycles. ${ }^{3}$

As a result, in both low and high lending growth cycles, loan quality is likely to deteriorate and conservatism can play a greater role to improve loan quality as there is more room for improvement. In turn, conservatism and future loan quality can be more positively associated in the low and high lending growth cycles than the moderate lending growth cycle. Based on the above reasoning, I set up the following hypothesis.

Hypothesis 3 : The impact of conservatism on loan portfolio quality is more pronounced during the low and high lending growth cycles than the moderate lending growth cycle.

\section{Research methodology}

\footnotetext{
${ }^{3}$ During the moderate lending cycle where loan volumes are ordinary and screening and monitoring over loan portfolios are normally conducted, incremental monitoring benefits from timely loss recognition would be insignificant.
} 


\subsection{Conservatism proxies}

(1) Khan and Watts (2009)' firm-level conservatism measure (C-Score)

Based on Beatty and Liao (2011), I use Khan and Watts (2009)'s bank-specific conditional conservatism measure based on Basu's (1997) differential timeliness of earnings measure. Since market returns should reflect information about both incurred losses and expected future losses, a greater association between negative returns and current reported net income is consistent with timelier provisioning of expected loan losses. Following prior research, I remove the observation with a price per share of less than $\$ 1$ and with a negative book value of equity. I also require at least 5 annual observations to run each regression.

$N I_{i t}=\beta_{0}+\beta_{1} D_{i t}+R_{i t}\left(\mu_{1}+\mu_{2} S I Z E_{i t}+\mu_{3} M B_{i t}+\mu_{4} L E V_{i t}\right)+D_{i t} R_{i t}\left(\lambda_{1 t}+\lambda_{2 t} S I Z E_{i t}+\lambda_{3 t} M B_{i t}+\right.$ $\left.\lambda_{4 t} L E V_{i t}\right)+\left(\delta_{1 t} S I Z E_{i t}+\delta_{2 t} M B_{i t}+\delta_{3 t} L E V_{i t}+\delta_{4 t} D_{i t} S I Z E_{i t}+\delta_{5 t} D_{i t} M B_{i t}+\delta_{6 t} D_{i t} L E V_{i t}\right)+\varepsilon_{t}$ (Eq.1)

Where NI: Net income (COMPUSTAT "ni") divided by lagged market value of equity (COMPUSTAT "csho" * share price at the fiscal quarter end).

$R$ : Annual returns compounded from monthly returns beginning the second month after fiscal quarter end.

$D$ : An indicator variable that equals 1 for negative returns, and zero otherwise.

$M V$ : Market value of equity, calculated as the natural log of market value of equity (COMPUSTAT "csho" * share price at the fiscal quarter end).

MTB: Market value of equity divided by book value of equity (COMPUSTAT “ceq").

LEV: Long term debt (COMPUSTAT "dltt") divided by market value of equity (COMPUSTAT "csho" * share price at the fiscal quarter end).

After Equation (1) is estimated, C-Score is constructed using the estimated coefficients as follows.

$$
C \text { - } \text { Core }_{i t}=\beta_{3}=\lambda_{1 t}+\lambda_{2 t} S_{S I Z E_{t}}+\lambda_{3 t} M B_{t}+\lambda_{4 t} L E V_{t}+\varepsilon \quad \text { (Eq.2) }
$$

By construction, the higher the C-Score, the more timely loss recognition. 
Furthermore, to understand better the sources of conservatism, I decompose the C-Score into two components: (i) loan loss provision conservatism $(C$-Score_LLP) and (ii) earnings before provision conservatism (C-Score_EBP) following Andreou et al. (2017). Specifically, I follow the same approach described above while replacing the dependent variable with either loan loss provision $(L L P)$, or earnings before provision $(E B P)$ then re-run the equation (1). Because conservatism is expected to manifest through manager's use of discretionary loan loss provision, CON_LLP is expected to drive the results.

(2) Loan loss provision asymmetry measure (LLP_ASY)

I develop another conservatism measure by modifying the approaches employed by Beatty and Liao (2011) and Bushman and Williams (2012). In developing a measure of delay in loss provisioning, Beatty and Liao (2011) estimate the equations where loan loss provisions are regressed on lagged, contemporaneous, and future changes in NPLs along with capital and earnings before provisions. Following Basu (1997)'s piece-wise linear regression where net income is regressed on positive and negative stock returns, I similarly modify Beatty and Liao (2011)'s model by decomposing the changes in NPLs into increase in NPLs (=bad news) and decrease in NPLs (=good news) and estimate the extent to which loss provisions reflect asymmetric timeliness of bad news relative to good news reflected in NPLs. Specifically, I estimate the following piece-wise linear model. To extract bank-quarter level conservatism measure, I run the rolling regressions for each bank-quarter using the observations of the past 3 years while requiring 12 observations for each regression. ${ }^{4}$

\footnotetext{
${ }^{4}$ Bushman and Williams (2012), using international sample, estimate a similar equation as above for each country, and use the coefficient on $\triangle N P L_{t+l}$ as a proxy for forward-looking discretion in loan provision and the coefficient on EBP as a proxy for smoothing discretion in loan provision.
} 


$$
\begin{aligned}
L L P_{t}= & \alpha_{0}+\alpha_{1} \Delta N P L_{t-2}+\alpha_{2} D \Delta N P L_{t-2}+\alpha_{3} D \triangle N P L_{t-2} * \Delta N P L_{t-2}+\alpha_{4} \Delta N P L_{t-1}+\alpha_{5} D \Delta N P L_{t-1} \\
& +\alpha_{6} D \Delta N P L_{t-1} * \Delta N P L_{t-1}+\alpha_{7} \Delta N P L_{t}+\alpha_{8} D \Delta N P L_{t}+\alpha_{9} D \Delta N P L_{t} * \Delta N P L_{t}+\alpha_{10} \Delta N P L_{t+1} \\
& +\alpha_{11} D \Delta N P L_{t+2}+\alpha_{12} D \Delta N P L_{t+1} * \Delta N P L_{t+1}+\alpha_{13} C A P I T A L_{t}+\alpha_{14} E B P_{t}+\varepsilon_{t}
\end{aligned}
$$

Where $D \triangle N P L_{t+x}$ is a dummy variable that is set to 1 for bad news for credit losses, that is, when $\triangle N P L_{t+x}$ is positive, and 0 otherwise. The capital ratio and earnings before provision are included to control for banks' incentives to manipulate provision to meet regulatory requirements or to smooth earnings.

I focus on the association between loan loss provisions and lagged, contemporaneous and future changes in $N P L$. More specifically, I use the lagged increase in $N P L\left(D \triangle N P L_{t-1} \triangle N P L_{t-1}\right)$, contemporaneous increase in NPL $\left(D \triangle N P L_{t} \triangle N P L_{t}\right)$, and future increase in $N P L\left(D \triangle N P L_{t+1}\right.$ $\left.\triangle N P L_{t+1}\right)$ to capture timelier recognition of loan losses versus gains. The more positive association between loan loss provisions and increases in $N P L$ for each time period is consistent with more conservatism, that is, bank managers who report conservatively will incorporate future increase in NPL faster than future decrease in $N P L$ in provision.

Therefore, the coefficient $\alpha_{3}, \alpha_{6}, \alpha_{9}$ and $\alpha_{12}$ capture the degree of conservative provisioning practice. I refer to the average of these four coefficients as loan loss provision asymmetry, denoted as LLP_ASY.

The coefficients on $D \triangle N P L_{t-2} \triangle N P L_{t-2}\left(\alpha_{3}\right)$, and $D \triangle N P L_{t-1} \triangle N P L_{t-1}\left(\alpha_{6}\right)$ capture the extent to which current provisions reflect past deteriorations in the performance of the loan portfolios. The coefficient on $D \triangle N P L_{t} \triangle N P L_{t}\left(\alpha_{9}\right)$ picks up the extent to which current provisions incorporate contemporaneous deteriorations in the quality of the loan portfolio, while the 
coefficient on $D \triangle N P L_{t+1} \triangle N P L_{t+1}\left(\alpha_{12}\right)$ picks up the extent to which current provisions explicitly anticipate future deteriorations in the performance of the loan portfolio. Because current GAAP requires an "incurred loss" methodology for recognizing credit losses that delays recognition until it is probable a loss has been incurred, I exclude $\alpha_{9}$ and $\alpha_{12}$ and only include the average of coefficients on lagged changes in NPLs. The inferences remain unchanged.

To reduce the measurement errors, I use an indicator variable that is equal to one if each conservatism measure is greater than the median during the quarter, and zero otherwise.

\subsection{Empirical models}

\subsubsection{Test of Hypothesis 1}

I use the following Equation 4 to test the hypothesis 1. I have included quarter fixed effects for all the regression analyses and statistical significance is based on heteroskedasticityrobust standard errors clustered by quarter.

$$
\begin{aligned}
L Q_{i t+1}= & \beta_{0}+\beta_{1} C_{C O N}+\beta_{2} L Q_{i t}+\beta_{3} S I Z E_{i t}+\beta_{4} A B S G A P_{i t}+\beta_{5} F E E_{i t}+\beta_{6} R O A V O L_{i t} \\
& +\beta_{7} E F F_{i t}+\beta_{8} E B L L P_{i t}+\beta_{9} L O A N_{i t}+\beta_{10} L G_{i t}+\beta_{11} C O M M_{i t}+\beta_{12} R E A L_{i t} \\
& +\beta_{13} C_{10 N S U M E R_{i t}+\beta_{14} C A P I T A L_{i t}+\beta_{15} L I Q U I D I T Y_{i t}+\beta_{16} C h g G D P_{i t}} \\
& \left.+ \text { Year dummies }+\varepsilon_{i t} \text { (Eq. } 4\right)
\end{aligned}
$$

Where $L Q$ represents loan portfolio quality measured by 1 year ahead non-performing loans (NPL) or net charge-offs (NCO). As bank monitoring effort is reflected in the bank asset quality (mainly loan portfolios), I use loan quality as a main proxy for bank monitoring effort. Berger and DeYoung (1997) argue that NPL is the most commonly agreed-upon definition of problem loans in both academic research and the trade press, and is difficult to manipulate by managers because loans much be reported as nonperforming if it is past due at least 90 days. While there is evidence that banks use discretionary loan charge-offs to manage capital prior to 
the 1989 regulatory change (Beatty, Chamberlain and Magliolo, 1995; Collins, Shackelford, and Wahlen, 1995), charge-offs are often driven by exogenous factors and also, some loans such as consumer loans are automatically charged off when they become delinquent for a certain number of days. Therefore, $N C O$ is also a relatively nondiscretionary measure of bank loan quality. Note that both $N P L$ and $N C O$ are a negative function of loan quality, so a negative sign on the coefficient on $C O N$ is consistent with the hypothesis. Additionally, I use two additional proxies for bank monitoring quality, namely the Z-Score and industry-median adjusted salary expense as a dependent variable for robustness checks. A more detailed description for these measures can be found in the robustness section.

$C O N$ is one of conservatism measures, that is, C-Score, $C$-Score_EBP, C-Score_LLP, and $L L P \_A S Y$. I control for variables known to affect loan quality, largely based on Bhat and Desai (2016). $L Q$ at time $t$ is included to control for the serial correlation. SIZE is the natural logarithm of bank total assets, $A B S G A P$ is the absolute value of one-year maturity gap deflated by total assets, FEE is the ratio of fee income to total income, ROAVOL is the standard deviation of $R O A$ over past 5 years, $E F F$ is the ratio of non-Interest Expense to income before extraordinary items, EBLLP is earnings before LLP, $L O A N$ is loans deflated by total assets, $L G$ is loan growth deflated by total assets, COMM is agricultural and commercial loans deflated by total assets, $R E A L$ is real estate loans deflated by total assets, CONSUMER is consumer loans deflated by total assets, CAPITAL is equity capital deflated by total assets, Liquidity is liquid assets deflated by total assets. Loan quality is expected to deteriorate during slow economic cycles so the change in GDP is controlled. $\triangle G D P$ is the quarterly GDP growth rate. All variables and their construction are detailed in the appendix A. 
A significantly positive coefficient on $\beta_{1}$ is consistent with the hypothesis that better $C O N$ is positively associated with banks' own monitoring effort.

\subsubsection{Test of Hypothesis 2A, 2B}

I modify Eq. (4) to test whether the association between conservatism and loan quality is stronger for firms with high risk-shifting incentives than firms with low risk-shifting incentives. I estimate the following model:

$$
\begin{aligned}
& L Q_{i t+1}=\beta_{0}+\beta_{1} \operatorname{CON}_{i t}+\beta_{2} \text { RISKSHIFT }_{i t}+\beta_{3} \operatorname{CON}_{i t} * \text { RISKSHIFT }_{i t}+\beta_{4} L Q_{i t}+\beta_{5} \text { SIZE }_{i t} \\
& +\beta_{6} A B S G A P_{i t}+\beta_{7} F E E_{i t}+\beta_{8} R O A V O L_{i t}+\beta_{9} E F F_{i t}+\beta_{10} E B L L P_{i t}+\beta_{11} L O A N_{i t} \\
& +\beta_{12} L G_{i t}+\beta_{13} C_{C O M M_{i t}}+\beta_{14} R E A L_{i t}+\beta_{15} \text { CONSUMER }_{i t}+\beta_{16} \text { CAPITAL }_{i t} \\
& +\beta_{17} L I Q U I D I T Y_{i t}+\beta_{18} C_{\text {ChgDPP }}+\operatorname{RISKSHIFT}^{*}\left(\mu_{1} L Q_{i t}+\mu_{2} \operatorname{SIZE}_{i t}\right. \\
& +\mu_{3} A B S G A P_{i t}+\mu_{4} F E E_{i t}+\mu_{5} R_{0 A V O L}+\mu_{6 t} E F F_{i t}+\mu_{7} E B L L P_{i t}+\mu_{8} L O A N_{i t} \\
& +\mu_{9} L G_{i t}+\mu_{10} \text { COMM }_{i t}+\mu_{11} \text { REAL }_{i t}+\mu_{12} \text { CONSUMER }_{i t}+\mu_{13} \text { CAPITAL }_{i t} \\
& \left.+\mu_{14} \text { LIQUIDITY }_{i t}+\mu_{15} \text { ChgGDP }_{i t}\right)+ \text { Year dummies }+\varepsilon_{i t}
\end{aligned}
$$

Where, RISKSHIFT is either a proxy of information asymmetry or distress risk. I also use a fully interacted model by including interaction variables among RISKSHIFT and control variables to allow the coefficients on control variables to vary with RISKSHIFT. ${ }^{5}$

Information asymmetries are measured in two ways. First measure, INFASY, is a marketbased measure, which is the average of standardized bid-ask spread, stock return volatility, and idiosyncratic risk.

Second measure is information asymmetries between the firm and debtholder reflected in the cost of borrowing. The borrower's perception of a bank's risk taking is reflected in the cost

\footnotetext{
${ }^{5}$ The results do not change without the interaction terms between conditioning variables and control variables.
} 
of borrowing because rational debtholders recognize managers' incentives to engage in risky activities and incorporate value implications of managers' future actions into the pricing of debt.

Specifically, I examine the imputed interest rate on large time deposits (jumbo certificates of deposit or JCD). ${ }^{6}$ I choose the jumbo-CD market to proxy for borrowers' perception of a bank's risk shifting incentives because most banks use this market as their primary source of marginal funds (Kishan and Opiela,2012).

\subsubsection{Test of Hypothesis 3}

The monitoring benefits of conservatism are likely to vary depending on the degree of information asymmetry between managers and capital providers. Presumably, during the low and high lending growth cycles which coincide with the economic boom and bust, information asymmetry on bank asset quality is more severe because the potential risk of generating problem loans are higher than normal times. Therefore, the monitoring benefits of conservatism are likely to be more prominent during the low and high lending growth cycles because conservatism can lower the negative consequences of information asymmetry by imposing timely reporting of expected loan losses.

To test this conjecture, I modify the Eq. (4) and include the dummy variables that capture the different states of the lending growth cycles (High, Moderate, and Low lending cycles) as well as the interaction between these dummy variables and $C O N$ to see whether the role of conservatism on loan monitoring effort changes under the different lending growth cycles. Following Andreou et al. (2017), I employ the following model:

$$
\begin{aligned}
L Q_{i t+1}= & \beta_{0}+\beta_{1} \mathrm{CON}_{i t}+\beta_{2} \mathrm{HIGH}_{t}+\beta_{3} \mathrm{CON}_{t} * \mathrm{HIGH}_{t}+\beta_{4} M O D_{t}+\beta_{5} \mathrm{CON}_{t} * M O D_{t} \\
& +\beta_{6} L O W_{t}+\beta_{7} \mathrm{CON}_{t} * L O W_{t}+\beta_{8} L Q_{i t}+\beta_{9} S_{I Z E_{i t}}+\beta_{10} A B S G A P_{i t}+\beta_{11} F E E_{i t}
\end{aligned}
$$

\footnotetext{
${ }^{6}$ JCD (more than \$100,000) were fully uninsured until Q3 2008 and partly uninsured (over \$250,000) afterward.
} 
$+\beta_{12} R_{\text {ROAVOL }}+\beta_{13}$ EFF $_{i t}+\beta_{14} E B L L P_{i t}+\beta_{15} L O A N_{i t}+\beta_{16} L G_{i t}+\beta_{17} C O M M_{i t}$

$+\beta_{18} R E A L_{i t}+\beta_{19}$ CONSUMER $_{i t}+\beta_{20}$ CAPITAL $_{i t}+\beta_{21}$ LIQUIDITY $_{i t}+\beta_{22}$ ChgGDP $i t$

+ Year dummies $+\varepsilon_{i t}$ (Eq. 6)

Where $C O N$ is one of the conservatism proxies, CON_LLP or CON_BS, and

$H I G H, M O D$, and $L O W$ are indicator variables that correspond to the high, moderate and low lending growth cycles, respectively. The high lending cycle variable gets the value of 1 for years 2000, 2005-2008, 2011-2015 and 0 otherwise. The moderate lending cycle variable is set to 1 for years 1994-1999 and 0 otherwise. The low lending cycle variable is set to 1 for years 2001-2004 and 2009-2010 and 0 otherwise. The negative coefficients of $C O N^{*} L O W$ and that of $C O N^{*} H I G H$ are consistent with Hypothesis 2, that conservatism plays a more prominent role in helping loan monitoring effort during the low and high lending growth cycles.

\section{Data}

The sample includes publicly traded bank holding companies in the United States during the 1994 to 2015 period. The sample period starts from 1994 because Bank Compustat does not report quarterly NPLs prior to 1993. I focus on publicly traded banks since stock price is an input of my conservatism measures. Stock prices of banks have been obtained from CRSP, and financial statement data are extracted from Bank Compustat Quarterly or the quarterly call report data (Y9C) from the Federal Reserve Bank of Chicago website. After removing bank-quarter observations with missing data for any variables used in the main analysis, the final sample consists of 18,358 bank-quarters representing 635 bank holding companies (BHC) when C-Score is used while 17,514 bank-quarters representing 600 unique BHCs when $L L P \_A S Y$ is used. All independent variables are winsorized at the $1 \%$ to help control for outliers in the sample. The descriptive statistics are provided in Panel A of Table 1. The mean NPL relative to total assets is 0.008 , while the mean NCO relative to total assets is 0.002 . The mean and median values of $C$ Score_LLP and $L L P \_A S Y$ are about 0.5 , indicating the sample is evenly distributed with regard 
to conservatism. The average bank in our sample has an asset of $\$ 14.92$ billion (median $=\$ 14.59$ billion) and the mean (median) equity capital ratio is $9.1 \%$ (8.9\%). The average bank derives about $25 \%$ of income from fee-generating activities such as advisory services. For the average bank in the sample, earnings before loan loss provisions represent 0.008 of total assets, the standard deviation of stock returns is $2.45 \%$. The average loan relative to assets is $66 \%$.

Table1, Panel B reports Pearson correlations. The correlation coefficients between NPL and $N C O$ is 0.581 , indicating while the loan quality proxies are substantially positively correlated, they capture different aspects of default risks. As predicted, both proxies of $C O N$ are significantly negatively correlated with the proxy for loan portfolio quality, providing initial evidence that conservatism improves bank asset quality through the discretionary channels of loan loss provisions. In addition, the CON proxies are positively and significantly correlated. However, as the correlation coefficients are below 1, they still capture somewhat different dimensions of $C O N$. Both $C O N$ proxies are positively related to SIZE, FEE, EFF, EBLLP, CONS, and LIQUID, indicating that banks with greater conservatism are likely to be large, profitable, and liquid and generate a larger proportion of their income from fees and consumer loans. $C O N$ proxies are negatively related to $L O A N, L G, C O M M$, and $R E$, indicating that banks with greater conservatism have lower loans relative to assets, lower loan growth, lower commercial and real estate lending.

\section{Results}

\subsection{Baseline results - Testing $\mathrm{H} 1$}

Table 2 summarizes the estimation results of the multivariate regressions testing whether conservatism helps to improve loan portfolio quality. Panel A (Panel B) uses the NPL $(N C O)$ as a dependent variable. Note that a negative coefficient on $C O N$ is consistent with the hypothesis 
that greater conservatism leads banks to improve their loan quality, presumably through enhanced monitoring over bank managers' lending decisions.

Column (1) reports the results from regressing $N P L$ on $C$-Score using ordinary least squares. After controlling for bank characteristics, the coefficient on $C O N$ is negative and statistically significant at the $10 \%$ level. In terms of economic significance, moving the $C$-Score dummy from 0 to 1 , with other independent variables held at their means, decreases $N P L$ relative to total loans by about $0.42 \%$. Column (2) and Column (3) report the results from regressing $N P L$ on decomposed C-Score, C-Score associated with EBP, and C-Score associated with $L L P$, respectively. In Column (2) when $C$-Score_EBP is used, the coefficient on $C O N$ is positive and insignificant $(\operatorname{coeff}=0.0007, \mathrm{~T}$-stat $=0.32)$, opposite to the predicted sign while in Column (3) when $C$-Score_LLP is used, the coefficient on $C O N$ is negative and highly significant at less than $1 \%$ level (coeff $=-0.0019$, T-stat=-22.60), confirming that the results reported in Column (1) is driven by $C$-Score_LLP, not $C$-Score_EBP. Moving $C$-Score_LLP dummy from 0 to 1 decreases NPL by $0.19 \%$, representing almost $28 \%$ decrease in NPL. Similarly, in Column (4) when $L L P \_A S Y$ is used, the coefficient on $C O N$ is negative and highly significant (coeff $=0.0030, \mathrm{~T}$ stat=42.08), representing almost $37 \%$ decrease in $N P L$.

In Panel B when NCO is used as a dependent variable, the inferences remain unchanged. Column (1) reports the results from regressing NCO on C-Score using ordinary least squares. The coefficient on $C$-Score_LLP is negative and statistically significant at the $1 \%$ level. In terms of economic significance, moving the $C$-Score_LLP from 0 to 1 , with other independent variables held at their means, decreases $N C O$ relative to total assets by about $0.07 \%$. Given the mean value of $N C O(0.002)$, it represents a decrease of $35 \%$ in NCO. Although the coefficient on $C O N$ is negative and significant across all $C$-Score measures (from Columns (1)-(3)), the 
statistical significance of $C$-Score_LLP is greater than that of $C$-Score_EBP, supporting the hypothesis that conservatism mainly operates through the discretionary application of $L L P$, not $E B P$ which is relatively non-discretionary. Similar results are obtained in Column (4) using $L L P \_A S Y$. The coefficient on $C O N$ is -0.0011 and statistically significant at the $5 \%$ level, consistent with the hypothesis that conservatism is associated with better loan portfolio quality. In sum, the effect of $C O N$ on loan quality is statistically and economically significant in improving loan quality, manifesting the monitoring roles of conservatism.

Turning to the control variables, the coefficient on $L Q$ is positive and significant across all columns, confirming the auto-correlation in loan quality year over year. The coefficient on SIZE is positive and significant, suggesting that larger banks have poorer loan quality. The coefficient on $A B S G A P$ is positive and significant, implying that the banks with higher interest risk have lower loan quality. The coefficient on $F E E$ is negative with $N P L$ as a dependent variable, and positive but not significant with $N C O$ as a dependent variable. A positive sign suggests that banks drawing a higher percentage of their income from fee generating activities rather than traditional deposit taking and lending activities have poorer loan quality, and vice versa. The coefficient on ROAVOL is positive, implying that banks with greater operating volatility have poorer loan quality. The coefficient on $E F F$ is negative, indicating that banks with higher cost efficiency have better loan portfolio quality. The coefficients on EBLLP, LOAN, and $L G$ are positive, indicating profitable banks, banks with higher loans to total asset ratio, and banks experiencing rapid growth in loans have poorer loan quality, consistent with Foos et al. (2010). The results on the coefficients on COMM, CONS, and RE are mixed. The coefficient on $C A P$ is mostly negative and significant, indicating that bank capitalization is positively associated with loan quality, consistent with Bhat and Desai (2016). This indicates that bank 
capital strengthens monitoring incentives which in turn improves loan quality. The coefficient on LIQUID is mostly negative, indicating liquid banks have better loan portfolio quality. The sign on the coefficient on the change in GDP is mostly negative, suggesting that improved economic condition leads to better loan quality.

For the remainder of the analyses, I only employ $C$-Score_LLP and $L L P \_A S Y$ as a dependent variable because the main results confirm that these two variables drive the results.

\subsection{Conservatism and risk taking incentive - testing $\mathrm{H} 2$}

Under H2A an d H2B, I predict that ex-ante information asymmetry or distress risk can contribute to risk-taking incentives, and thus, the disciplinary effect of conservatism on loan quality would be more pronounced for the group of banks having greater risk-taking incentives. Table 3, Panel A and B contains the results of estimating Eq. (5) for each of two information asymmetry proxies. In Panel A, the coefficient $\beta_{3}$ on the interaction between $C O N$ and INFASY is negative and significant across both $C O N$ and $L Q$ measures. Similarly in Panel B, the interaction term between $C O N$ and $J C D$ loads negatively and significantly, suggesting that the contribution of conservatism to improve loan quality is greater when information asymmetry is high. Overall, these findings suggest that the monitoring benefits of conservatism are greater for firms subject to larger information asymmetries, as predicted.

Under H2B, I predict that greater distress risk affects the disciplinary effect of conservatism on loan quality. I examine this issue in Table 4, panels A and B, using two different measures of distress risk. In Panel $\mathrm{A}$, the coefficient $\beta_{3}$ on the interaction between $C O N$ and LOWCAP is negative and significant across both $C O N$ and $L Q$ measures. Similarly, in Panel B, the coefficient on the interaction between CON and POORPERF loads negatively and 
significantly, suggesting that the contribution of conservatism to improve loan quality is greater when distress risk is high. For both Table 3 and Table 4, the main effect of $C O N$ on loan quality is still present. Overall, these findings suggest that the monitoring benefits of conservatism are incrementally greater for banks subject to larger information asymmetry, as these banks are likely to take more risk.

5.3. Conservatism and bank lending growth cycle - testing $\mathrm{H} 3$

The results are reported in Table 5. With NPL as a LQ proxy, only the coefficients of $C O N^{*} L O W$ and $C O N^{*} H I G H$ are negative while the coefficient of $C O N^{*} M O D$ is insignificant, as predicted. With NCO as a dependent variable, all interaction variables, $C O N^{*} L O W, C O N^{*} M O D$, and $C O N^{*} H I G H$, are negative and significant with the statistical significance of $C O N^{*} M O D$ being only marginal at the $10 \%$ level. Overall, the results support Hypothesis 3 that the monitoring benefit of conservatism to facilitate bank's own monitoring effort is more pronounced during the extreme lending growth cycles when banks would likely carry lower quality loan portfolios than normal times.

6. Additional analyses

6.1. Subsample analysis according to size

I examine how the impact of conservatism on loan portfolio quality varies across banks depending on their size. A number of studies have addressed the issue of lending performance by large and small banks separately (e.g., Beatty and Liao, 2011). Because the type of information used in the evaluation of a loan as well as organizational structure are significantly different depending on the size of the bank, it is important to check whether the relation between CON and loan quality documented so far also applies to all banks regardless of their size. 
There are reasons to believe that the relation between conservatism and loan monitoring effort may be greater for smaller banks than for larger banks. Smaller banks are inherently more subject to greater information asymmetry. For firms with more unverifiable information or greater information asymmetry, it is also costly for outsiders to evaluate managers' investment decisions and overall firm performance (Smith and Watts, 1992; Gaver and Gaver, 1993; LaFond and Watts, 2008). Therefore, managers in these firms have greater latitude to indulge their own preferences, regardless of shareholders' interests. Conservatism is thus likely to play an even more important role in reducing managers' incentives to make unprofitable and risky investment decisions for smaller banks.

Alternatively, conservatism may not be a good indicator of information quality for smaller banks, weakening the relationship between conservatism and loan quality for smaller banks. For example, smaller banks are the main loan providers for smaller firms. Small business lending by small banks is characterized by relationship development and non-standardized loans. The literature suggests that relationship banking information may be a better source of information about small business credit worthiness than "hard," quantitative information such as accounting reports or credit scores (e.g., Greenbaum et al.,1998; Diamond, 1991; Petersen and Rajan, 1994). This indicates that financial reporting quality may not be a good indicator of monitoring effort for smaller banks. Because this paper theorizes that monitoring effort underpins the influence of $C O N$ on loan quality, the connection between $C O N$ and loan quality can be weaker for smaller banks.

The banks are classified as small if banks have total assets between $\$ 500$ million and $\$ 1$ billion, medium if banks have total assets between 1 billion and 3 billion, and large if banks have total assets more than 3 billion. I estimate Eq. (4) within each subsample. Results are reported in 
Table 6. Table 6, Panel A presents the results of estimating Eq. (4) for large, medium, and small banks, respectively, using $C$-Score_LLP as a conservatism proxy. The coefficient on $C O N$ is significantly negative for all banks regardless of size, for both $L Q$ proxies. The same inferences are obtained when $L L P \_A S Y$ is used as a conservatism proxy in Panel $\mathrm{B}$. The results suggest that the monitoring benefits associated with conservatism exist regardless of the bank size.

\subsection{Change specifications}

The results are consistent with the notion that conservatism affects the banks' monitoring effort in their loan portfolios. However, other variables could be correlated with both conservatism and loan portfolio quality. Furthermore, if both conservatism and loan portfolio quality are choices of the banks, my analyses could suffer from endogeneity. In this section, I attempt to rule out correlated omitted variables and endogeneity as potential concerns. I estimate the baseline regression in first-differences where change in loan quality (change from $\mathrm{t}+1$ to $\mathrm{t}+2$ ) is regressed on change in $C O N$ and change in control variables (change from $\mathrm{t}$ to $\mathrm{t}+1$ ). Employing a first-differenced specification mitigates the effect of bank-specific characteristics that are relatively constant over time.

The results are reported in Table 7. Regardless of the choice of CON proxy or loan quality proxy, the coefficient on $\triangle C O N$ is negative and significant indicating that an increase in $C O N$ is associated with an increase in monitoring effort (although only weakly significant with the change in NCO as a dependent variable). An alternative approach is to include bank fixed effects in the regression. Untabulated results indicate that the coefficients on all CON proxies are negative and statistically significant when including bank fixed effects. 


\subsection{Use of alternative asset quality measure}

My analysis is based on the assumption that better loan quality is the outcome of increased monitoring efforts. To shed further light that this premise is reasonable, I use two alternative measures to capture the degree of bank monitoring in this section.

The first measure is the Z-Score, which is often used to measure overall bank risk. The premise behind using Z-Score as a proxy for monitoring is that bank risk is expected to decrease with heightened monitoring effort. Specifically, the Z-Score measures the distance from insolvency. Insolvency is defined as a state in which losses exceed equity $(E<\pi)$ (where $\mathrm{E}$ is equity and $\pi$ is profits). The probability of insolvency, therefore, can be expressed as probability $(-R O A<C A R)$, where $R O A(\pi / \mathrm{A})$ is the return on assets and $C A R(=\mathrm{E} / \mathrm{A})$ is the capital assets ratio. Following the literature, I define the inverse of the probability of insolvency as the z-score. If profits are normally distributed, then the inverse of the probability of insolvency equals $(R O A+C A R) / \sigma(R O A)$, where $\sigma(R O A)$ is the standard deviation of ROA. A higher Z-score indicates that the bank is more stable. Following Laeven and Levine (2009) who advocate the use of the log of the Z-Score over the simple Z-Score on the basis that the latter's distribution is heavily skewed, whereas the former's is not, I use the natural logarithm of the z-score, which is normally distributed. ${ }^{7}$

As another alternative proxy of monitoring quality, I use salary expense following Coleman et al. (2006) and Bhat and Desai (2016). The main presumption is that the quality and quantity of bank staffs reflect its loan screening/monitoring effort and ability. As this proxy focuses on inputs rather than outputs of banks' monitoring effort, it is less likely to be related to bank' risk or risk preference (Lee and Sharp, 2009). Using similar measure, Coleman, Esho, and

\footnotetext{
${ }^{7}$ For brevity, I use " $z$-score"' to refer to the natural logarithm of the z-score in the remainder of the paper.
} 
Sharpe (2006) find that salary expense reliably predicts future loan losses. Following Bhat and Desai (2016), I use the median adjusted salary expense to total non-interest expense ratio as an alternative dependent variable capturing banks' loan monitoring effort. Because bank size and loan composition affect salary expense significantly, the median salary is calculated for each size tercile within the tercile based on the ratio of commercial loans to total assets for each quarter. Unlike consumer loans which are mostly homogenous and monitored as pools, commercial loans are heterogeneous and takes more individual efforts to monitor, requiring higher salary expense for the same amount of loans.

The results are reported in Table 8. In Columns (1) and (2) when Z-Score is used as an alternative monitoring quality, the coefficient on $C O N$ is statistically significant and negative, and the results are not sensitive to which $C O N$ proxy is used, corroborating a positive relation between $C O N$ and monitoring effort. The consistent results obtained using SALEXP (in Columns (3) and (4)) provides assurance that loan quality reasonably captures the banks monitoring efforts.

6.4. Corporate governance subsample analysis

Leventis, Dimitropoulos, and Owusu-Ansah (2013) argue that effective governance structures result in better monitoring of management and hence will favor the implementation of conservative accounting because greater accounting conservatism is needed to reduce the likelihood of managers' manipulation and to enhance the quality of accounting information. Consistent with this view, they find that well-governed banks engage in significantly higher levels of conservatism in their financial reporting practices. If greater conservatism is associated strong corporate governance, then one may question that the results found in this study is driven 
by corporate governance, not conservatism per se. Therefore, I examine whether the improved loan quality associated with conservatism differs for well-governed and poorly-governed firms. If corporate governance drives the results, then the results should be stronger for the wellgoverned banks.

I divide the sample into weak and strong governance subsamples and repeat the regression analysis on these two subsamples. I use Gompers, Ishii, and Metrick (2003)'s G-score as a summary (inverse) measure of the strength of firms' corporate governance. Firms whose $G$ score equals or exceeds the median for the full sample are classified as "weak governance", and the remainder are placed in the "strong governance" subsample.

The results for corporate governance subsamples are shown in Panels A and B of Table 9. The results hold in both subsamples partitioned based on the full sample median of the corporate governance. This confirms that the results documented in the paper are attributable to the benefits of conservatism, not corporate governance.

\section{Conclusion}

This study provides evidence on the monitoring benefits of bank financial transparency defined as conservatism or timelier recognition of expected loan losses. I find robust evidence that banks' quality of loan portfolios measured by the future levels of nonperforming loans or charge offs is increasing in conservatism. Furthermore, the findings suggest that this effect is greater when banks are likely to experience deteriorating loan portfolio quality, such as during the low and high lending growth cycles. Moreover, banks benefit from conservatism regardless of their size. 
While the banking literature posits that transparency can promote bank stability by enhancing market discipline of banks' risk-taking decisions, there is no research directly looking into the relation between transparency and bank's own monitoring effort. Using financial reporting conservatism as a proxy of transparency, this study finds robust evidence that conservatism improves banks' monitoring effort. Additionally, despite ample evidence on conservatism improving investment efficiency in nonfinancial firms, no study to date investigates this relation in the banking sector. Viewing loan portfolio quality as the outcome of banks' main investment decisions, this study contributes to the investment efficiency literature that the benefit of conservatism in improving investment efficiency extends to the banking sector. Also, this study adds to the literature on bank financial reporting transparency by highlighting its impact on bank risk monitoring effort. Given the benefits of bank transparency is shared by lenders as well as borrowers, these findings should be of interest to regulators and policymakers who debate ways to incentivize banks to use their discretion inherent in loan loss provisioning in ways that is more informative and less opportunistic. 


\section{References}

Acharya, V.V., M. Richardson. 2009. Restoring Financial Stability: How to Repair a Failed System. John Wiley \& Sons, Hoboken, N.J.

Acharya, V.V., Mora, N., 2015. A crisis of banks as liquidity providers. J. Finance 70(1), 1-43.

Akins, B., Y., Dou, and J. Ng, 2017. Corruption in lending: The role of timely loan loss recognition. Journal of Accounting and Economics. 64 (2-3):453-478.

Andreou, P.C., Cooper, I., Louca, C., and Philip, D. 2017. Bank loan loss accounting treatment, credit cycles and crash risk. The British Accounting Review 49(5): 474-492

Andries, K., Gallemore, J., and Jacob, M. 2017. The Effect of Corporate Taxation on Bank Transparency: Evidence from Loan Loss Provisions. Journal of Accounting and Economics 63(2-3):307-328.

Armstrong, C., W. Guay, and J. Weber. 2010. The Role of Information and Financial Reporting in Corporate Governance and Debt Contracting. Journal of Accounting and Economics 50 (2-3) : 179-234.

Avery, R.A., Berger, A.N., 1991. Risk-based capital and deposit insurance reform. J. Bank. Financ. 15 (4-5), 251-267.

Basu, S. (1997). The conservatism principle and the asymmetric timeliness of earnings. Journal of Accounting and Economics, 24(1), 3-37.

Beatty, A., Chamberlain, S., Magliolo, J., 1995. Managing financial reports of commercial banks: the influence of taxes, regulatory capital, and earnings. Journal of Accounting Research 33 (2), 231-261.

Beatty, A., S. Chamberlain \& J. Magliolo. (1995). Managing financial reports of commercial banks: The influence of taxes, regulatory capital, and earnings. Journal of Accounting Research

Beatty, A., Liao, S., 2011. Do delays in expected loss recognition affect banks' willingness to lend? Journal of Accounting \& Economics 52, 1-20

Beatty, A., and S. Liao. 2014. Financial Accounting in the Banking Industry: A Review of the Empirical Literature. Journal of Accounting and Economics 58, (2-3) : 339-383.

Berger, A.N., \& DeYoung, R. (1997). Problem loans and cost efficiency in commercial banks. Journal of Banking and Finance, 21(6), 849-870.

Berger, A. \& Udell, G. (2004). The institutional memory hypothesis and the procyclicality of bank lending behavior. Journal of Financial Intermediation, 13(4), 438-495. 
Bhat, G. and H. Desai. Bank Capital Structure and Loan Monitoring (April 27, 2017). Available at SSRN: https://ssrn.com/abstract=2789168 or http://dx.doi.org/10.2139/ssrn.2789168

Bushman, R., and A. Smith. 2001. Financial Accounting Information and Corporate Governance. Journal of Accounting and Economics 32 (1-3) : 237-333.

Bushman, R., Williams, C., 2012. Accounting discretion, loan loss provisioning, and discipline of banks' risk-taking. Journal of Accounting \& Economics 54, 1-18.

Bushman, R., Williams, C., 2015. Delayed Expected Loss Recognition and the Risk Profile of Banks. Journal of Accounting Research 53(3), 511-553.

Bushman, R. (2016). Transparency, accounting discretion, and bank stability. Economic Policy Review 22 (1)

Coleman ADF, Esho N, Sharpe IG. 2006. Does bank monitoring influence loan contract terms? Journal of Financial Services Research 30:177-198.

Collins, J., Shackelford, D., Wahlen, J., 1995. The coordination of regulatory capital, earnings, and taxes for banks. Journal of Accounting Research 33, 263 - 292.

Dell'Ariccia, G., and R. Marquez. Lending Booms and Lending Standards. Journal of Finance 61 (2006): 2511-46.

Diamond, D. (1991). Monitoring and reputation: The choice between bank loans and directly placed debt. Journal of Political Economy, 99, 689-721.

Dugan, J., (2009). "Loan Loss Provisioning and Procyclicality", Remarks during the Institute of International Bankers, March.

Foos, D., Norden, L., Weber, M., 2010. Loan growth and riskiness of banks. Journal of Banking and Finance 32, 2929-2940.

García Lara, J. M., Garcia Osma, B., \& Penalva, F. 2016. Conditional conservatism and firm investment efficiency. Journla of Accounting and Economics 61 :221-238.

Gaver, J.J. \& Gaver, K. M., 1993. Additional evidence on the association between the investment opportunity set and corporate financing, dividend, and compensation policies. Journal of Accounting and Economics, 16, 125-160.

Gompers, P., Ishii, J., \& Metrick, A. (2003). Corporate governance and equity prices. The Quarterly Journal of Economics, 118(1), 107-156.

Greenbaum, S., Kanastas,C., Venezia, I. 1989. Equilibrium loan pricing under bank-client relationship, Journal of Banking and Finance, $13: 221-235$ 
Jokipii,T., and Milne, A. 2011. Bank capital buffer and risk adjustment decisions. Journal of Financial Stability 7 (3) ;165-178

Khan, M.S, \& Watts, R. L. (2009). Estimation and empirical properties of a firm-year measure of accounting conservatism. J. Account. Econ., 48(2-3): 132-150.

Kishan, R.P., Opiela, T.P., 2012. Monetary policy, bank lending, and the risk-pricing channel. J. Money Credit Bank. 44 (4), 573-602.

Laeven, L. and Levine, R. (2009) Bank Governance, Regulation and Risk Taking. Journal of Financial Economics, 93, 259-275.

LaFond, R. and Watts, R.L. (2008) The Information Role of Conservative Financial Statements. The Accounting Review, 83, 447-478

Leventis, S., Dimitropoulos, P., and Owusu-Ansah, S. 2013. Corporate governance and accounting conservatism: Evidence from the banking industry. Corporate Governance: An International Review 21 (3) 264-286.

Liu, C. and Ryan, S. 1995. The Effect of Bank Loan Portfolio Composition on the Market Reaction to and Anticipation of Loan Loss Provisions. Journal of Accounting Research, 33, 77 94.

Liu, C. and Ryan, S. 2006. Income Smoothing over the Business Cycle: Changes in Banks' Coordinated Management of Provisions for Loan Losses and Loan Charge-Offs from the Pre1990 Bust to the 1990s Boom. The Accounting Review, 81, 421-441.

Manganaris, P., Beccalli, E., and Dimitropoulos, P. 2017. Bank transparency and the crisis. The British Accounting Review (49):121-137.

Morgan, D., 2002. Rating banks: risk and uncertainty in an opaque industry. Amererican Economic Review 92, 874-888.

Nichols, D., Wahlen, J and Wieland, M. 2009. Publicly Traded Versus Privately Held: Implications for Conditional Conservatism in Bank Accounting, Review of Accounting Studies, $14,88-122$.

Petersen, M., and Rajan, R., 1994. The benefits of lending relationships: evidence from small business data. Journal of Finance 49, 3-37.

Rochet, J. C. 2005. Prudential Policy. Monetary and Economic Studies (Special Edition) October 2005: 93-119.

Shrieves, R.E., Dahl, A., 1992. The relationship between risk and capital in commercial banks. J. Bank. Financ. 16 (2), 439-457. 
Smith, C. W. Jr., Watts, R. L., 1992. The investment opportunity set and corporate financing, dividend and compensation policies. Journal of Financial Economics, 32, 263- 292.

Stephanou, C. 2010. Rethinking Market Discipline in Banking: Lessons from the Financial Crisis. Policy Research Working Paper 5227, The World Bank.

Vyas, D., 2011. The timeliness of accounting write-downs by U.S. financial institutions during the financial crises of 2007-2008. Journal of Accounting Research 49, 823-860.

Watts, R.L., 2003, Conservatism in accounting Part I: explanations and implications, Accounting Horizons, 3, 207-221. 


\section{Appendix}

\section{Variable description}

\begin{tabular}{|c|c|}
\hline Variable & Description \\
\hline \multicolumn{2}{|c|}{ Dependent Variables : } \\
\hline NPL & $\begin{array}{l}\text { Non-performing Loans (bhck5525+bhck5526) deflated by total assets (bhck2170) } \\
\text { or Compustat "npatq/atq" }\end{array}$ \\
\hline $\mathrm{CO}$ & $\begin{array}{l}\text { Net charge off(bhck4635-bhck4605) deflated by total assets (bhck2170) or } \\
\text { Compustat "ncoq/atq" }\end{array}$ \\
\hline Z-Score & $\begin{array}{l}\text { A negative value of the natural logarithm of the moving average of the return on } \\
\text { assets (bhck } 4300 / \text { bhck2170) over the preceding } 12 \text { quarters plus the capital to } \\
\text { asset ratio (bhck3210/bhck2170) divided by the standard deviation of return on } \\
\text { assets. The standard deviation of return on assets is calculated on a moving } \\
\text { average basis over the preceding twelve quarters. }\end{array}$ \\
\hline AdjSalExp & $\begin{array}{l}\text { The median adjusted salary expense to total non-interest expense ratio, where the } \\
\text { median salary is calculated for each size tercile within the tercile based on the } \\
\text { ratio of commercial loans to total assets for each quarter or Compustat "xstfwsq/ } \\
\text { xnitbq" }\end{array}$ \\
\hline \multicolumn{2}{|c|}{ Conservatism (CON) measures: } \\
\hline C-Score & $\begin{array}{l}N I_{i t}=\beta_{0}+\beta_{1} D_{i t}+R_{i t}\left(\mu_{1}+\mu_{2} S I Z E_{i t}+\mu_{3} M B_{i t}+\mu_{4} L E V_{i t}\right)+D_{i t} R_{i t}\left(\lambda_{1 t}+\lambda_{2 t} S I Z E_{i t}+\right. \\
\left.\lambda_{3 t} M B_{i t}+\lambda_{4 t} L E V_{i t}\right)+\left(\delta_{I t} S I Z E_{i t}+\delta_{2 t} M B_{i t}+\delta_{3 t} L E V_{i t}+\delta_{4 t} D_{i t} S I Z E_{i t}+\delta_{5 t} D_{i t} M B_{i t}+\right. \\
\left.\delta_{6 t} D_{i t} L E V_{i t}\right)+\varepsilon_{t} \quad(1) \\
\text { Where NI: Net income (Compustat "ni") divided by lagged market value of } \\
\text { equity (Compustat "csho"* share price at the fiscal quarter end). } \\
R \text { : Annual returns compounded from monthly returns beginning the second } \\
\text { month after fiscal quarter end. } \\
D \text { : An indicator variable that equals } 1 \text { for negative returns, and zero otherwise. } \\
M V \text { : Market value of equity, calculated as the natural log of market value of } \\
\text { equity (Compustat "csho" * share price at the fiscal quarter end). } \\
M T B \text { : Market value of equity divided by book value of equity (Compustat "ceq"). } \\
L E V \text { : Long term debt (Compustat "dltt") divided by market value of equity } \\
\text { (Compustat "csho" * share price at the fiscal quarter end). }\end{array}$ \\
\hline
\end{tabular}




\begin{tabular}{|c|c|}
\hline & $\begin{array}{l}\text { After Equation (1) is estimated, C-Score is constructed using the estimated } \\
\text { coefficients as follows. } \\
\qquad C \text {-Score } e_{i t}=\beta_{3}=\lambda_{1 t}+\lambda_{2 t} S I Z E_{t}+\lambda_{3 t} M B_{t}+\lambda_{4 t} L E V_{t}+\varepsilon \\
\text { To reduce the measurement errors, I use an indicator variable that is equal to } \\
\text { one if } C \text {-Score is greater than the median during the quarter, and zero otherwise. }\end{array}$ \\
\hline C-Score_LLP & $\begin{array}{l}\text { Conservatism associated with loan loss provisions (C-Score_LLP) } \\
L L P_{i t}=\beta_{0}+\beta_{1} D_{i t}+R_{i t}\left(\mu_{1}+\mu_{2} S I Z E_{i t}+\mu_{3} M B_{i t}+\mu_{4} L E V_{i t}\right)+D_{i t} R_{i t}\left(\lambda_{1 t}+\right. \\
\left.\lambda_{2 t} S I Z E_{i t}+\lambda_{3 t} M B_{i t}+\lambda_{t t} L E V_{i t}\right)+\left(\delta_{1 t} S I Z E_{i t}+\delta_{2 t} M B_{i t}+\delta_{3 t} L E V_{i t}+\delta_{4 t} D_{i t} S I Z E_{i t}+\right. \\
\left.\delta_{5 t} D_{i t} M B_{i t}+\delta_{6 t} D_{i t} L E V_{i t}\right)+\varepsilon_{t}(1 A) \\
\text { Where LLP is provision (bhck4230) deflated by total assets (bhck2170). } \\
\text { After Equation (1A) is estimated, C-Score_LLP is constructed using the estimated } \\
\text { coefficients as follows. } \\
\qquad C \text {-Score_LLP } L P_{i t}=\beta_{3}=\lambda_{1 t}+\lambda_{2 t} S I Z E_{t}+\lambda_{3 t} M B_{t}+\lambda_{4 t} L E V_{t}+\varepsilon \\
\text { To reduce the measurement errors, I use an indicator variable that is equal to } \\
\text { one if } C \text {-Score_LLP is greater than the median during the quarter, and zero } \\
\text { otherwise. }\end{array}$ \\
\hline C-Score_EBP & $\begin{array}{l}\text { Conservatism associated with earnings before provision conservatism ( } L L P_{i t} \\
E B P_{i t}=\beta_{0}+\beta_{1} D_{i t}+R_{i t}\left(\mu_{1}+\mu_{2} S I Z E_{i t}+\mu_{3} M B_{i t}+\mu_{4} L E V_{i t}\right)+D_{i t} R_{i t}\left(\lambda_{1 t}+\right. \\
\left.\lambda_{2 t} S I Z E_{i t}+\lambda_{3 t} M B_{i t}+\lambda_{4 t} L E V_{i t}\right)+\left(\delta_{1 t} S I Z E_{i t}+\delta_{2 t} M B_{i t}+\delta_{3 t} L E V_{i t}+\delta_{4 t} D_{i t} S I Z E_{i t}+\right. \\
\left.\delta_{5 t} D_{i t} M B_{i t}+\delta_{6 t} D_{i t} L E V_{i t}\right)+\varepsilon_{t}(1 B) \\
\text { Where EBP is earnings (bhck } 4300)+ \text { Loan loss provision (bhck 4230) deflated } \\
\text { by total assets (bhck 2170). } \\
\text { After Equation (1B) is estimated, C-Score_EBP is constructed using the } \\
\text { estimated coefficients as follows. } \\
\qquad \text {-Score_EBP } E P_{i t}=\beta_{3}=\lambda_{1 t}+\lambda_{2 t} S I Z E_{t}+\lambda_{3 t} M B_{t}+\lambda_{4 t} L E V_{t}+\varepsilon \\
\text { To reduce the measurement errors, I use an indicator variable that is equal to one } \\
\text { if } C \text {-Score_EBP is greater than the median during the quarter, and zero otherwise. }\end{array}$ \\
\hline LLP_ASY & $\begin{array}{l}\text { I run the rolling regressions for each bank-quarter using the observations of the } \\
\text { past } 3 \text { years while requiring } 12 \text { observations for each regression. } \\
\begin{aligned} P R O V_{t}= & \alpha_{0}+\alpha_{1} \Delta N P L_{t-2}+\alpha_{2} D \triangle N P L_{t-2}+\alpha_{3} D \Delta N P L_{t-2} * \Delta N P L_{t-2}+\alpha_{4} \Delta N P L_{t-1} \\
& +\alpha_{5} D \triangle N P L_{t-1}+\alpha_{6} D \triangle N P L_{t-1} * \Delta N P L_{t-1}+\alpha 7 \Delta N L_{t}+\alpha_{8} D \Delta N P L_{t} \\
& +\alpha_{9} D \Delta N P L_{t} * \Delta N P L_{t}+\alpha_{10} \Delta N P L_{t+1}+\alpha_{11} D \Delta N P L_{t+2} \\
& +\alpha_{12} D \Delta N P L_{t+1} * \Delta N P L_{t+1}+\alpha_{13} C A P I T A L_{t}+\alpha_{14} E B P_{t}+\varepsilon_{t}\end{aligned}\end{array}$ \\
\hline
\end{tabular}

\footnotetext{
${ }^{8}$ Bushman and Williams (2012), using international sample, estimate a similar equation as above for each country, and use the coefficient on $\triangle N P L_{t+l}$ as a proxy for forward-looking discretion in loan provision and the coefficient on EBP as a proxy for smoothing discretion in loan provision.
} 


\begin{tabular}{|c|c|}
\hline & $\begin{array}{l}\text { Where } D \triangle N P L_{t+x} \text { is a dummy variable that is set to } 1 \text { for bad news for credit } \\
\text { losses, that is, when } \triangle N P L_{t+x} \text { is positive, and } 0 \text { otherwise. } \\
\text { LLP_ASY is an indicator variable that is equal to one if the average of the } \\
\text { coefficients } \alpha_{3,} \alpha_{6,} \alpha_{9} \text { and } \alpha_{12} \text { is above median, and zero otherwise. }\end{array}$ \\
\hline \multicolumn{2}{|c|}{ Conditioning Variables (RISKSHIFT) } \\
\hline INFASY & $\begin{array}{l}\text { An average of standardized values of bid-ask spread, volatility and idiosyncratic } \\
\text { risk, where Bid-Ask Spread equals the annual average of daily spread scaled by } \\
\text { the midpoint between bid and ask; Volatility equals the annualized variance of } \\
\text { the individual stock returns for the previous } 250 \text { trading days obtained from } \\
\text { CRSP; Idiosyncratic risk equals the natural logarithm of the standard deviation o } \\
\text { the residuals from a market-model regression of excess returns on value-weighted } \\
\text { market excess returns for } 60 \text { months (with at least } 24 \text { observations). }\end{array}$ \\
\hline $\begin{array}{l}\text { JCD (Jumbo } \\
\text { Certificates of } \\
\text { Deposit) rate }\end{array}$ & $\begin{array}{l}\text { JCD rate equals interest expense on JCDs divided by quarterly average of JCDs. } \\
\text { (RIAD4174 (or RIADA517) /RCON3345 (or RCONA415) x 4) } \\
\text { Interest expenses on JCDs: Till 1966Q4: RIAD4174; from 1997Q3a: RIADA517 } \\
\text { Quarterly average of JCDs : Till 1996Q4: RCON3345; from 1997Q1: } \\
\text { RCONA514 } \\
\text { The interest expenses on jumbo CDs (RIAD4174 and RIADA517) cumulate } \\
\text { yearly and therefore I take first differences within each year to obtain quarterly } \\
\text { interest expenses. Furthermore, I multiply the fraction by four to receive annual } \\
\text { CD rates. The definition of the CD rate follows Acharya and Mora (2015) and } \\
\text { Kishan and Opiela (2012). }\end{array}$ \\
\hline LOWCAP & $\begin{array}{l}\text { An indicator variable that gets } 1 \text { if a bank's level of balance sheet capital(equity } \\
\text { capital (bhck3210) deflated by total assets (bhck2170)) is less than } 7 \% \text { and } 0 \\
\text { otherwise. }\end{array}$ \\
\hline POORPERF & $\begin{array}{l}\text { An indicator variable that gets } 1 \text { if a bank' ROE is in the bottom quintile and } 0 \\
\text { otherwise. }\end{array}$ \\
\hline \multicolumn{2}{|c|}{ Control Variables : } \\
\hline SIZE & Log of total assets (bhck2170) or Compustat "atq" \\
\hline
\end{tabular}




\begin{tabular}{|c|c|}
\hline ABSGAP & $\begin{array}{l}\text { Absolute value of one-year maturity gap } \\
\text { ("bhck3197+bhck3296+bhck3298+bhck3409") deflated by total assets } \\
\text { ("bhck } 2170 \text { ") }\end{array}$ \\
\hline FEE & $\begin{array}{l}\text { Ratio of fee income (bhck4079) deflated by total interest income } \\
\text { ("bhck4074+bhck4079") or Compustat "(fccq+ idilbcq)/ niintq" }\end{array}$ \\
\hline ROAVOL & $\begin{array}{l}\text { The standard deviation of return on asset ("bhck } 4300 / \text { bhck } 2170 \text { "), calculated on a } \\
\text { moving average basis over the preceding twelve quarters. Or Compustat "piq/atq" }\end{array}$ \\
\hline EFF & $\begin{array}{l}\text { Ratio of non-Interest expense ( "bhck } 4093+\text { bhck } 4300 \text { ") deflated by total assets } \\
\text { ( bhck2170) or Compustat "xnitbq /atq" }\end{array}$ \\
\hline EBLLP & $\begin{array}{l}\text { Earnings before provision(bhck4300+bhck4230) deflated by total assets } \\
\text { (bhck2170) or Compustat "(piq+pclq)/atq" }\end{array}$ \\
\hline LOAN & Loan (bhck2122) deflated by total assets (bhck2170) or Compustat "Intalq/atq" \\
\hline LG & 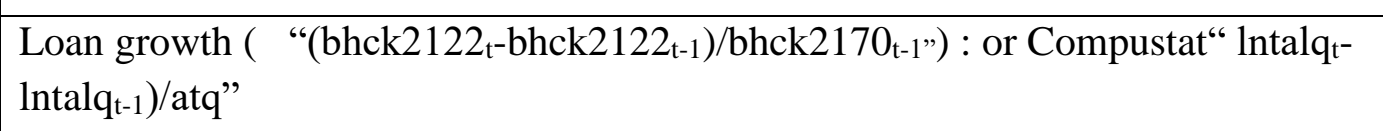 \\
\hline COMM & $\begin{array}{l}\text { Agricultural and commercial loans( "bhck1763+bhck1764+bhck1590") deflated } \\
\text { by total assets (bhck2170) }\end{array}$ \\
\hline $\mathrm{RE}$ & Real estate loans (bhck1410) deflated by total assets (bhck2170) \\
\hline CONS & $\begin{array}{l}\text { Consumer loans ( "bhck2008+bhck2011+bhckb538+bhckb539") deflated by total } \\
\text { assets (bhck2170) }\end{array}$ \\
\hline CAPITAL & $\begin{array}{l}\text { Equity capital ( bhck3210) deflated by total assets (bhck2170) or Compustat } \\
\text { "capr1q" }\end{array}$ \\
\hline LIQUIDITY & $\begin{array}{l}\text { Liquid assets } \\
\text { ( "bhck0081+bhck0395+bhck0397+bhck1773+bhck1350+bhck0276+bhck0277+ } \\
\text { bhdmB987") deflated by total assets (bhck2170) }\end{array}$ \\
\hline$\Delta \mathrm{GDP}$ & $\begin{array}{l}\text { Quarterly change in GDP from St. Louis Federal Reserve website } \\
\text { https://research.stlouisfed.org/fred2/ }\end{array}$ \\
\hline
\end{tabular}


Table 1 Panel A

Descriptive Statistics

\begin{tabular}{|c|c|c|c|c|}
\hline Variable & $\mathrm{N}$ & Mean & Median & Std Dev \\
\hline \multicolumn{5}{|c|}{ Dependent variables } \\
\hline$N P L$ & 18,358 & 0.008 & 0.005 & 0.010 \\
\hline $\mathrm{NCO}$ & 18,358 & 0.002 & 0.001 & 0.003 \\
\hline \multicolumn{5}{|c|}{ Independent variables } \\
\hline Cscore_LLP & 18,358 & 0.505 & 0.556 & 0.272 \\
\hline$L L P \_A S Y$ & 17,514 & 0.502 & 0.500 & 0.351 \\
\hline \multicolumn{5}{|c|}{ Control variables } \\
\hline SIZE & 18,358 & 14.918 & 14.591 & 1.331 \\
\hline$A B S G A P$ & 18,358 & 0.673 & 0.659 & 0.224 \\
\hline$F E E$ & 18,358 & 0.247 & 0.233 & 0.109 \\
\hline ROAVOL & 18,358 & 0.004 & 0.003 & 0.001 \\
\hline$E F F$ & 18,358 & 0.025 & 0.023 & 0.013 \\
\hline$E B L L P$ & 18,358 & 0.008 & 0.007 & 0.005 \\
\hline$L O A N$ & 18,358 & 0.661 & 0.673 & 0.107 \\
\hline$L G$ & 18,358 & 0.122 & -0.037 & 0.630 \\
\hline COMM & 18,358 & 0.122 & 0.108 & 0.071 \\
\hline$R E$ & 18,358 & 0.453 & 0.454 & 0.140 \\
\hline CONS & 18,358 & 0.056 & 0.036 & 0.056 \\
\hline CAP & 18,358 & 0.091 & 0.089 & 0.021 \\
\hline LIQUID & 18,358 & 0.231 & 0.219 & 0.101 \\
\hline$\triangle G D P$ & 18,358 & 0.025 & 0.027 & 0.017 \\
\hline
\end{tabular}


Panel B: Correlation Analysis

\begin{tabular}{|c|c|c|c|c|c|c|c|c|c|c|c|c|c|c|c|c|c|}
\hline Variable & $\mathrm{NCO}$ & Cscore_LLP & $L L P \_A S Y$ & SIZE & $A B S G A P$ & $F E E$ & ROAVOL & $E F F$ & $E B L L P$ & $L O A N$ & $L G$ & COMM & $R E$ & CONS & $C A P$ & LIQUID & $\triangle G D P$ \\
\hline \multirow[t]{2}{*}{$N P L$} & 0.581 & -0.136 & -0.479 & 0.005 & 0.024 & -0.074 & 0.123 & -0.190 & -0.055 & 0.258 & 0.173 & -0.035 & 0.348 & -0.287 & 0.106 & -0.100 & -0.543 \\
\hline & $(0.000)$ & $(0.000)$ & $(0.000)$ & $(0.482)$ & $(0.000)$ & $(0.000)$ & $(0.000)$ & $(0.000)$ & $(0.000)$ & $(0.000)$ & $(0.000)$ & $(0.000)$ & $(0.000)$ & $(0.000)$ & $(0.000)$ & $(0.000)$ & $(0.000)$ \\
\hline \multirow[t]{2}{*}{$\mathrm{NCO}$} & & -0.144 & -0.376 & 0.128 & 0.109 & 0.013 & 0.186 & 0.124 & 0.273 & 0.216 & 0.112 & 0.074 & 0.120 & -0.013 & -0.020 & -0.170 & -0.391 \\
\hline & & $(0.000)$ & $(0.000)$ & $(0.000)$ & $(0.000)$ & $(0.056)$ & $(0.000)$ & $(0.000)$ & $(0.000)$ & $(0.000)$ & $(0.000)$ & $(0.000)$ & $(0.000)$ & $(0.048)$ & $(0.003)$ & $(0.000)$ & $(0.000)$ \\
\hline \multirow[t]{2}{*}{ Cscore_LLP } & & & 0.082 & 0.025 & -0.087 & 0.058 & 0.015 & 0.054 & 0.076 & -0.120 & -0.013 & -0.035 & -0.085 & 0.025 & 0.177 & 0.079 & 0.003 \\
\hline & & & $(0.000)$ & $(0.001)$ & $(0.000)$ & $(0.000)$ & $(0.044)$ & $(0.000)$ & $(0.000)$ & $(0.000)$ & $(0.074)$ & $(0.000)$ & $(0.000)$ & $(0.001)$ & $(0.000)$ & $(0.000)$ & $(0.657)$ \\
\hline \multirow[t]{2}{*}{$L L P \_A S Y$} & & & & 0.202 & -0.131 & 0.128 & -0.017 & 0.127 & 0.037 & -0.154 & -0.051 & -0.008 & -0.213 & 0.138 & -0.008 & 0.072 & 0.388 \\
\hline & & & & $(0.000)$ & $(0.000)$ & $(0.000)$ & $(0.027)$ & $(0.000)$ & $(0.000)$ & $(0.000)$ & $(0.000)$ & $(0.266)$ & $(0.000)$ & $(0.000)$ & $(0.275)$ & $(0.000)$ & $(0.000)$ \\
\hline \multirow[t]{2}{*}{ SIZE } & & & & & -0.039 & 0.539 & 0.076 & 0.080 & 0.142 & -0.189 & 0.088 & 0.190 & -0.413 & 0.144 & -0.010 & -0.015 & -0.001 \\
\hline & & & & & $(0.000)$ & $(0.000)$ & $(0.000)$ & $(0.000)$ & $(0.000)$ & $(0.000)$ & $(0.000)$ & $(0.000)$ & $(0.000)$ & $(0.000)$ & $(0.127)$ & $(0.030)$ & $(0.897)$ \\
\hline \multirow[t]{2}{*}{$A B S G A P$} & & & & & & -0.018 & 0.056 & -0.016 & 0.002 & 0.209 & -0.024 & 0.222 & 0.053 & 0.045 & -0.140 & -0.212 & 0.006 \\
\hline & & & & & & (0.009) & $(0.000)$ & $(0.015)$ & $(0.805)$ & $(0.000)$ & $(0.000)$ & $(0.000)$ & $(0.000)$ & $(0.000)$ & $(0.000)$ & $(0.000)$ & $(0.343)$ \\
\hline \multirow[t]{2}{*}{$F E E$} & & & & & & & 0.016 & 0.290 & 0.129 & -0.256 & 0.029 & 0.081 & -0.382 & 0.101 & -0.029 & 0.111 & -0.003 \\
\hline & & & & & & & $(0.015)$ & $(0.000)$ & $(0.000)$ & $(0.000)$ & $(0.000)$ & $(0.000)$ & $(0.000)$ & $(0.000)$ & $(0.000)$ & $(0.000)$ & $(0.658)$ \\
\hline \multirow[t]{2}{*}{ ROAVOL } & & & & & & & & 0.073 & 0.180 & 0.099 & 0.038 & 0.041 & 0.063 & -0.032 & 0.105 & -0.073 & -0.019 \\
\hline & & & & & & & & $(0.000)$ & $(0.000)$ & $(0.000)$ & $(0.000)$ & $(0.000)$ & $(0.000)$ & $(0.000)$ & $(0.000)$ & $(0.000)$ & $(0.004)$ \\
\hline \multirow[t]{2}{*}{$E F F$} & & & & & & & & & 0.773 & -0.043 & -0.051 & 0.057 & -0.158 & 0.164 & 0.062 & -0.044 & 0.164 \\
\hline & & & & & & & & & $(0.000)$ & $(0.000)$ & $(0.000)$ & $(0.000)$ & $(0.000)$ & $(0.000)$ & $(0.000)$ & $(0.000)$ & $(0.000)$ \\
\hline \multirow[t]{2}{*}{$E B L L P$} & & & & & & & & & & 0.047 & -0.029 & 0.093 & -0.103 & 0.165 & 0.142 & -0.079 & 0.077 \\
\hline & & & & & & & & & & $(0.000)$ & $(0.000)$ & $(0.000)$ & $(0.000)$ & $(0.000)$ & $(0.000)$ & $(0.000)$ & $(0.000)$ \\
\hline \multirow[t]{2}{*}{ LOAN } & & & & & & & & & & & 0.065 & 0.223 & 0.710 & 0.035 & 0.055 & -0.605 & -0.131 \\
\hline & & & & & & & & & & & $(0.000)$ & $(0.000)$ & $(0.000)$ & $(0.000)$ & $(0.000)$ & $(0.000)$ & $(0.000)$ \\
\hline \multirow[t]{2}{*}{$L G$} & & & & & & & & & & & & 0.005 & 0.080 & -0.108 & 0.058 & -0.009 & -0.124 \\
\hline & & & & & & & & & & & & $(0.501)$ & $(0.000)$ & $(0.000)$ & $(0.000)$ & $(0.184)$ & $(0.000)$ \\
\hline \multirow[t]{2}{*}{ COMM } & & & & & & & & & & & & & -0.333 & 0.021 & 0.007 & -0.125 & 0.040 \\
\hline & & & & & & & & & & & & & $(0.000)$ & $(0.002)$ & $(0.304)$ & $(0.000)$ & $(0.000)$ \\
\hline \multirow[t]{2}{*}{$R E$} & & & & & & & & & & & & & & -0.374 & 0.074 & -0.356 & -0.236 \\
\hline & & & & & & & & & & & & & & $(0.000)$ & $(0.000)$ & $(0.000)$ & $(0.000)$ \\
\hline \multirow[t]{2}{*}{ CONS } & & & & & & & & & & & & & & & -0.113 & -0.160 & 0.261 \\
\hline & & & & & & & & & & & & & & & $(0.000)$ & $(0.000)$ & $(0.000)$ \\
\hline \multirow[t]{2}{*}{ CAP } & & & & & & & & & & & & & & & & -0.002 & -0.105 \\
\hline & & & & & & & & & & & & & & & & $(0.774)$ & $(0.000)$ \\
\hline
\end{tabular}


Table 2 Analysis of the effect of CON on Loan Quality

Panel A: Using NPL as a dependent variable

\begin{tabular}{|c|c|c|c|c|c|c|c|c|c|c|c|c|}
\hline & \multicolumn{12}{|c|}{ Dep Var $=N P L$ at $t+1$} \\
\hline & \multirow{2}{*}{\multicolumn{3}{|c|}{$\begin{array}{c}C O N=C-S c o r e \\
\text { (1) }\end{array}$}} & \multirow{2}{*}{\multicolumn{2}{|c|}{$C O N=C-S c o r e \_E B P$}} & & \multirow{2}{*}{\multicolumn{2}{|c|}{$C O N=C-S c o r e \_L L P$}} & & \multirow{2}{*}{\multicolumn{3}{|c|}{$C O N=L L P_{-} A S Y$}} \\
\hline & & & & & & & & & & & & \\
\hline & Coeff & $T$-stat & & Coeff & $T$-stat & & Coeff & $T$-stat & & Coeff & $T$-stat & \\
\hline Intercept & -0.0006 & -0.25 & & -0.0007 & -0.30 & & -0.0045 & -7.62 & $* * *$ & 0.0009 & 0.26 & \\
\hline CON & -0.0042 & -2.42 & $*$ & 0.0007 & 0.32 & & -0.0019 & -22.60 & $* * *$ & -0.0030 & -42.08 & $* * *$ \\
\hline$L Q$ & 0.6796 & 37.21 & $* * *$ & 0.6876 & 37.58 & $* * *$ & 0.6655 & 30.35 & $* * *$ & 0.6669 & 108.11 & $* * *$ \\
\hline$\widetilde{S I Z E}$ & 0.0001 & 1.99 & & 0.0001 & 1.63 & & 0.0001 & 1.66 & & 0.0002 & 7.21 & $* * *$ \\
\hline$A B S G A P$ & 0.0015 & 28.12 & $* * *$ & 0.0015 & 30.67 & $* * *$ & 0.0016 & 7.44 & $* * *$ & 0.0015 & 14.24 & $* * *$ \\
\hline FEE & -0.0008 & -2.05 & & -0.0009 & -2.20 & & -0.0005 & -0.90 & & -0.0018 & -6.75 & $* * *$ \\
\hline ROAVOL & 0.2620 & 6.31 & $* * *$ & 0.2789 & 6.45 & $* * *$ & 0.3002 & 6.07 & $* * *$ & 0.2985 & 7.74 & $* * *$ \\
\hline$E F F$ & -0.0271 & -3.78 & $* *$ & -0.0256 & -3.63 & $* *$ & -0.0270 & -4.32 & $* *$ & -0.0187 & -4.27 & $* *$ \\
\hline$E B L L P$ & 0.0802 & 9.84 & $* * *$ & 0.0716 & 10.15 & $* * *$ & 0.0815 & 4.63 & $* *$ & 0.0656 & 6.16 & $* * *$ \\
\hline$L O A N$ & 0.0038 & 4.99 & $* *$ & 0.0038 & 5.19 & $* *$ & 0.0012 & 0.78 & & 0.0036 & 4.76 & $* *$ \\
\hline$L G$ & 0.0003 & 8.99 & $* * *$ & 0.0003 & 10.20 & $* * *$ & 0.0003 & 6.73 & $* * *$ & 0.0003 & 8.15 & $* * *$ \\
\hline COMM & -0.0022 & -3.43 & $* *$ & -0.0022 & -3.74 & $* *$ & -0.0004 & -0.30 & & -0.0032 & -5.79 & $* *$ \\
\hline$R E$ & 0.0003 & 0.65 & & 0.0003 & 0.67 & & 0.0020 & 2.05 & & -0.0002 & -0.34 & \\
\hline CONS & -0.0023 & -3.52 & $* *$ & -0.0024 & -3.99 & $* *$ & 0.0007 & 0.42 & & -0.0026 & -7.61 & $* * *$ \\
\hline$C A P$ & -0.0044 & -5.49 & $* *$ & -0.0050 & -4.15 & $* *$ & -0.0026 & -0.67 & & -0.0038 & -3.44 & $* *$ \\
\hline LIQUID & -0.0025 & -4.83 & $* *$ & -0.0026 & -4.76 & $* *$ & -0.0030 & -2.44 & $*$ & -0.0031 & -5.00 & $* *$ \\
\hline$\triangle G D P$ & -0.1088 & -0.92 & & -0.0962 & -0.86 & & 0.1374 & 1.57 & & -0.1658 & -1.21 & \\
\hline $\begin{array}{l}\text { Year } \\
\text { dummies } \\
\text { Adj. } R\end{array}$ & Yes & & & Yes & & & Yes & & & & & \\
\hline square & $76.13 \%$ & & & $76.06 \%$ & & & $75.27 \%$ & & & $75.95 \%$ & & \\
\hline No. obs & 18,358 & & & 18,358 & & & 18,358 & & & 17,514 & & \\
\hline
\end{tabular}

The table reports the OLS regression results of the effect of CON on loan quality. All variables are winsorized at 1th and 99th percentiles. Please refer to the appendix for the definitions of these variables. Heteroskedasticity-robust t-statistics are in the parentheses. Significance at the $10 \%, 5 \%$, and $1 \%$ level is indicated by $* * *$ and $* * *$ respectively. 
Panel B: Using NCO as a dependent variable

\begin{tabular}{|c|c|c|c|c|c|c|c|c|c|c|c|c|}
\hline & \multicolumn{12}{|c|}{ Dep Var $=N C O$ at $t+1$} \\
\hline & \multirow{2}{*}{\multicolumn{3}{|c|}{$\begin{array}{c}\text { CON=C-Score } \\
\text { (1) }\end{array}$}} & \multicolumn{3}{|c|}{$C O N=C-S c o r e_{-} E B P$} & \multirow{2}{*}{\multicolumn{3}{|c|}{$\begin{array}{c}C O N=C-S_{\text {(3) }}\end{array}$}} & \multicolumn{3}{|c|}{$\underset{\text { (4) }}{C O N=L L P}{ }_{-} A S Y$} \\
\hline & Coeff ${ }^{(1}$ & $T$-stat & & Coeff & & & Coeff & & & Coeff & $T$-stat & \\
\hline Intercept & -0.0046 & -2.03 & & -0.0045 & -1.97 & & -0.0009 & -8.53 & $* * *$ & -0.0043 & -1.77 & \\
\hline CON & -0.0025 & -3.92 & $* *$ & -0.0007 & -2.53 & $*$ & -0.0007 & -5.84 & ** & -0.0011 & -4.64 & ** \\
\hline $\mathrm{CO}$ & 0.5851 & 26.60 & $* * *$ & 0.5965 & 30.59 & $* * *$ & 0.5834 & 36.61 & $* * *$ & 0.5762 & 27.97 & $* * *$ \\
\hline SIZE & 0.0001 & 5.96 & $* * *$ & 0.0001 & 5.44 & $* *$ & 0.0001 & 5.46 & $* *$ & 0.0002 & 5.91 & $* * *$ \\
\hline$A B S G A P$ & 0.0004 & 4.30 & $* *$ & 0.0004 & 4.70 & $* *$ & 0.0004 & 4.47 & $* *$ & 0.0004 & 7.20 & $* * *$ \\
\hline$F E E$ & -0.0010 & -17.24 & $* * *$ & -0.0010 & -20.07 & $* * *$ & -0.0009 & -29.17 & $* * *$ & -0.0013 & -10.31 & $* * *$ \\
\hline ROAVOL & 0.1285 & 4.52 & $* *$ & 0.1391 & 4.54 & $* *$ & 0.1396 & 4.29 & $* *$ & 0.1417 & 6.16 & $* * *$ \\
\hline$E F F$ & 0.0075 & 3.39 & $* *$ & 0.0079 & 3.39 & $* *$ & 0.0063 & 2.90 & $*$ & 0.0135 & 6.02 & $* * *$ \\
\hline$E B L L P$ & 0.0551 & 6.48 & $* * *$ & 0.0492 & 5.86 & $* * *$ & 0.0569 & 7.80 & $* * *$ & 0.0399 & 5.87 & $* * *$ \\
\hline$L O A N$ & 0.0016 & 5.05 & $* *$ & 0.0016 & 5.22 & $* *$ & 0.0017 & 4.27 & $* *$ & 0.0021 & 5.03 & $* *$ \\
\hline$L G$ & 0.0001 & 17.35 & $* * *$ & 0.0001 & 33.04 & $* * *$ & 0.0001 & 15.35 & $* * *$ & 0.0001 & 5.76 & $* *$ \\
\hline СОММ & -0.0002 & -4.63 & $* *$ & -0.0003 & -6.65 & $* * *$ & -0.0006 & -5.07 & $* *$ & -0.0010 & -9.45 & $* * *$ \\
\hline$R E$ & -0.0005 & -3.97 & $* *$ & -0.0005 & -4.35 & $* *$ & -0.0007 & -4.91 & $* *$ & -0.0009 & -4.76 & $* *$ \\
\hline CONS & 0.0007 & 2.68 & $*$ & 0.0007 & 2.36 & $*$ & 0.0002 & 0.85 & & 0.0004 & 2.08 & \\
\hline CAP & -0.0048 & -5.65 & $* *$ & -0.0054 & -6.25 & $* * *$ & -0.0042 & -4.21 & $* *$ & -0.0053 & -8.56 & $* * *$ \\
\hline LIQUID & -0.0004 & -5.71 & $* *$ & -0.0005 & -5.46 & $* *$ & -0.0004 & -2.92 & $*$ & -0.0003 & -1.90 & \\
\hline$\triangle G D P$ & 0.0943 & 1.11 & & 0.0948 & 1.13 & & -0.0349 & -2.27 & & 0.0645 & 0.68 & \\
\hline $\begin{array}{l}\text { Year } \\
\text { dummies } \\
\text { Adj. } R\end{array}$ & Yes & & & Yes & & & Yes & & & Yes & & \\
\hline square & $62.13 \%$ & & & $62.74 \%$ & & & $61.90 \%$ & & & $62.39 \%$ & & \\
\hline No. obs & 18,358 & & & 18,358 & & & 18,358 & & & 17,514 & & \\
\hline
\end{tabular}


Table 3 The conditional effect of information asymmetry on the relation between conservatism and loan quality Panel A : Information asymmetry measured by the market measure

\begin{tabular}{|c|c|c|c|c|c|c|c|c|c|c|c|c|}
\hline & \multicolumn{6}{|c|}{ Dep Var $=N P L$ at $t+1$} & \multicolumn{6}{|c|}{ Dep Var $=N C O$ at $t+1$} \\
\hline & \multicolumn{3}{|c|}{$\begin{array}{c}C O N=C-S c o r e \_L L P \\
(1)\end{array}$} & \multicolumn{2}{|c|}{$C O N=L L P \_A S Y$} & & \multicolumn{2}{|c|}{$C O N=C-S c o r e \_L L P$} & & \multicolumn{3}{|c|}{$C O N=L L P \_A S Y$} \\
\hline & Coeff & $T$-stat & & Coeff & $T$-stat & & Coeff & T-stat & & Coeff & T-stat & \\
\hline Intercept & -0.0067 & -5.18 & $* *$ & -0.0006 & -0.71 & & -0.0058 & -2.02 & & -0.0094 & -2.88 & $*$ \\
\hline$C O N$ & -0.0006 & -6.10 & $* * *$ & -0.0025 & -12.36 & $* * *$ & -0.0009 & -11.71 & $* * *$ & -0.0009 & -3.77 & $* *$ \\
\hline INFASY & -0.0033 & -14.78 & $* * *$ & 0.0013 & 0.96 & & -0.0043 & -2.63 & $*$ & -0.0026 & -9.73 & $* * *$ \\
\hline$C O N * I N F A S Y$ & -0.0003 & -2.46 & * & -0.0011 & -3.01 & $*$ & -0.0004 & -2.14 & $*$ & -0.0004 & -4.48 & $* *$ \\
\hline$L Q$ & 0.5446 & 37.20 & $* * *$ & 0.6826 & 46.57 & $* * *$ & 0.8236 & 46.94 & $* * *$ & 0.5785 & 28.02 & $* * *$ \\
\hline$L Q * I N F A S Y$ & -0.0349 & -3.30 & $* *$ & -0.0467 & -2.73 & $*$ & -0.0222 & -2.09 & & -0.0451 & -3.67 & $* *$ \\
\hline$S I Z E^{*} I N F A S Y$ & 0.0001 & 41.50 & $* * *$ & -0.0001 & -2.51 & $*$ & 0.0001 & 6.42 & $* * *$ & 0.0001 & 4.85 & $* *$ \\
\hline$A B S G A P * I N F A S Y$ & 0.0006 & 5.60 & $* *$ & 0.0004 & 4.44 & $* *$ & 0.0003 & 1.73 & & 0.0005 & 3.85 & $* *$ \\
\hline$F E E^{*} I N F A S Y$ & -0.0003 & -3.77 & $* *$ & 0.0022 & 6.31 & $* * *$ & -0.0003 & -0.58 & & 0.0000 & 0.06 & \\
\hline ROAVOL *INFASY & 0.1065 & 6.02 & $* * *$ & -0.1007 & -1.81 & & 0.0723 & 2.88 & $*$ & 0.0747 & 2.92 & $*$ \\
\hline$E F F^{*} I N F A S Y$ & 0.0161 & 5.08 & $* *$ & -0.0391 & -4.66 & $* *$ & -0.0104 & -2.93 & $*$ & 0.0095 & 3.69 & $* *$ \\
\hline$E B L L P * I N F A S Y$ & 0.0195 & 3.08 & $*$ & 0.0438 & 2.09 & & 0.0234 & 2.30 & & 0.0175 & 2.21 & \\
\hline$L O A N * I N F A S Y$ & 0.0006 & 0.79 & & 0.0076 & 6.17 & $* * *$ & 0.0040 & 5.06 & $* *$ & -0.0004 & -0.55 & \\
\hline$L G^{*} I N F A S Y$ & 0.0001 & 3.06 & $*$ & 0.0000 & -0.73 & & 0.0000 & 0.43 & & 0.0001 & 2.09 & \\
\hline$C O M M * I N F A S Y$ & 0.0002 & 0.24 & & -0.0105 & -8.28 & $* * *$ & -0.0023 & -1.39 & & 0.0007 & 1.10 & \\
\hline$R E * I N F A S Y$ & 0.0016 & 2.45 & $*$ & -0.0033 & -2.79 & $*$ & 0.0003 & 0.23 & & 0.0024 & 4.98 & $* *$ \\
\hline CONS*INFASY & -0.0007 & -0.76 & & -0.0069 & -5.83 & $* *$ & -0.0030 & -4.86 & $* *$ & 0.0014 & 2.18 & \\
\hline$C A P^{*} I N F A S Y$ & 0.0001 & 0.04 & & -0.0045 & -1.53 & & 0.0010 & 0.39 & & -0.0011 & -1.05 & \\
\hline$L I Q U I D * I N F A S Y$ & 0.0002 & 0.80 & & -0.0004 & -0.65 & & 0.0006 & 0.93 & & 0.0001 & 0.43 & \\
\hline$\triangle G D P^{*} I N F A S Y$ & -0.0054 & -2.81 & $*$ & 0.0068 & 0.90 & & 0.0015 & 0.18 & & -0.0075 & -3.81 & $* *$ \\
\hline$S I Z E$ & 0.0001 & 4.92 & $* *$ & 0.0002 & 4.17 & $* *$ & 0.0000 & 1.09 & & 0.0002 & 4.90 & $* *$ \\
\hline$A B S G A P$ & 0.0004 & 5.63 & $* *$ & 0.0014 & 7.54 & $* * *$ & 0.0008 & 3.75 & $* *$ & 0.0003 & 5.81 & $* *$ \\
\hline$F E E$ & -0.0008 & -3.33 & $* *$ & -0.0004 & -0.41 & & 0.0001 & 0.25 & & -0.0010 & -3.47 & $* *$ \\
\hline ROAVOL & 0.0909 & 5.40 & $* *$ & 0.2541 & 4.66 & $* *$ & 0.1123 & 2.68 & $*$ & 0.0969 & 7.03 & $* * *$ \\
\hline$E F F$ & 0.0067 & 2.48 & $*$ & -0.0369 & -4.03 & $* *$ & -0.0212 & -1.20 & & 0.0111 & 4.65 & $* *$ \\
\hline$E B L L P$ & 0.0717 & 8.97 & $* * *$ & 0.0532 & 3.25 & $* *$ & 0.0681 & 6.71 & $* * *$ & 0.0537 & 5.47 & $* *$ \\
\hline
\end{tabular}




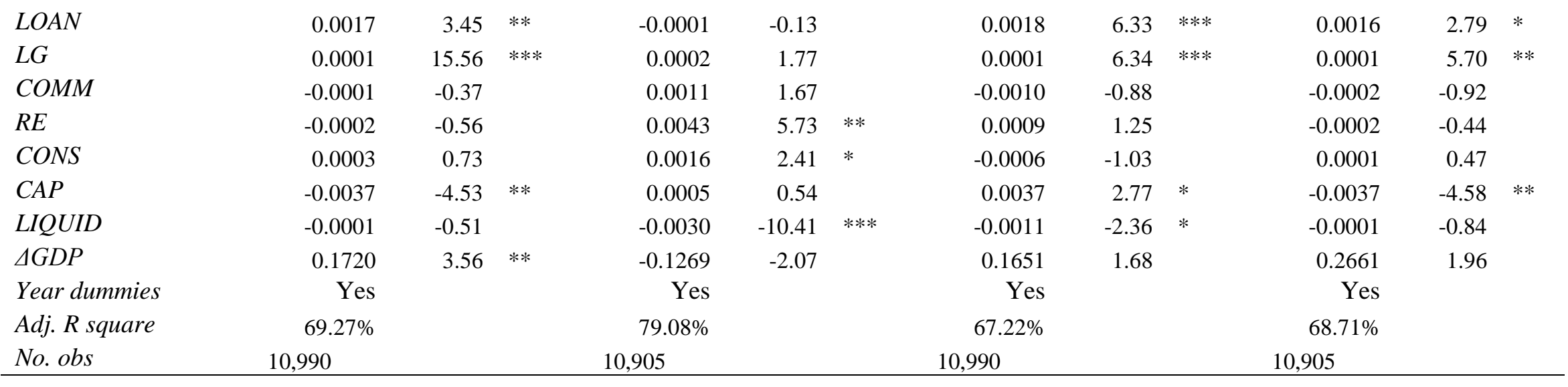

Panel B: Information asymmetry measured by JDC rate

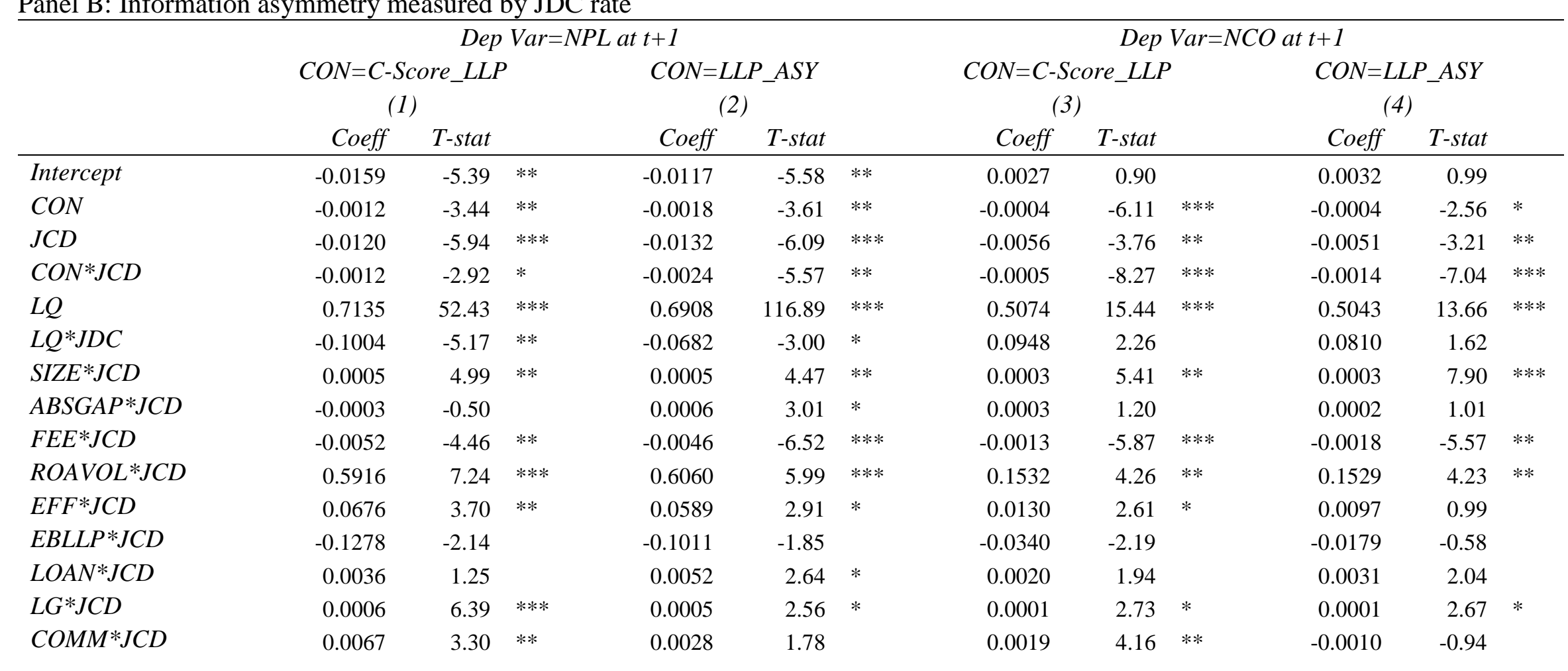




\begin{tabular}{|c|c|c|c|c|c|c|c|c|c|c|c|c|}
\hline$R E^{*} J C D$ & 0.0029 & 3.13 & $*$ & 0.0004 & 0.42 & & -0.0001 & -0.11 & & -0.0021 & -1.75 & \\
\hline CONS*JCD & 0.0004 & 0.32 & & -0.0019 & -3.44 & $* *$ & 0.0004 & 0.38 & & -0.0007 & -0.44 & \\
\hline$C A P^{*} J C D$ & -0.0038 & -1.20 & & -0.0027 & -0.84 & & 0.0065 & 2.07 & & 0.0042 & 1.41 & \\
\hline$L I Q U I D * J C D$ & 0.0038 & 1.35 & & 0.0039 & 1.84 & & 0.0008 & 2.32 & & 0.0002 & 0.38 & \\
\hline$\triangle G D P^{*} J C D$ & -0.0172 & -0.79 & & 0.0261 & 1.49 & & -0.0205 & -1.59 & & -0.0135 & -1.19 & \\
\hline SIZE & -0.0002 & -1.66 & & 0.0000 & -0.24 & & -0.0001 & -1.67 & & 0.0000 & -0.32 & \\
\hline$A B S G A P$ & 0.0015 & 6.55 & $* * *$ & 0.0011 & 13.90 & $* * *$ & 0.0002 & 1.66 & & 0.0002 & 1.46 & \\
\hline$F E E$ & 0.0015 & 1.26 & & 0.0003 & 0.57 & & -0.0005 & -3.34 & $* *$ & -0.0005 & -2.38 & $*$ \\
\hline ROAVOL & 0.0328 & 0.57 & & 0.0390 & 0.72 & & 0.0760 & 1.85 & & 0.0767 & 1.96 & \\
\hline$E F F$ & -0.0613 & -4.04 & $* *$ & -0.0472 & -3.40 & $* *$ & 0.0014 & 0.49 & & 0.0090 & 1.38 & \\
\hline$E B L L P$ & 0.1513 & 3.89 & $* *$ & 0.1171 & 3.61 & $* *$ & 0.0624 & 6.58 & $* * *$ & 0.0412 & 1.87 & \\
\hline$L O A N$ & 0.0017 & 0.81 & & 0.0017 & 1.39 & & 0.0004 & 0.83 & & 0.0006 & 0.93 & \\
\hline$L G$ & 0.0000 & 0.20 & & 0.0001 & 0.81 & & 0.0001 & 6.28 & $* * *$ & 0.0001 & 1.35 & \\
\hline COMM & -0.0068 & -7.53 & $* * *$ & -0.0057 & -13.25 & $* * *$ & -0.0012 & -9.56 & $* * *$ & -0.0003 & -0.67 & \\
\hline$R E$ & -0.0016 & -3.30 & $* *$ & -0.0007 & -0.94 & & -0.0004 & -1.53 & & 0.0002 & 0.39 & \\
\hline CONS & -0.0034 & -4.27 & $* *$ & -0.0019 & -3.99 & $* *$ & 0.0001 & 0.22 & & 0.0006 & 0.64 & \\
\hline$C A P$ & 0.0009 & 0.40 & & -0.0024 & -1.28 & & -0.0065 & -2.75 & $*$ & -0.0069 & -3.74 & $* *$ \\
\hline LIQUID & -0.0048 & -2.50 & $*$ & -0.0049 & -4.00 & $* *$ & -0.0010 & -4.93 & $* *$ & -0.0005 & -1.80 & \\
\hline$\triangle G D P$ & 0.9082 & 7.30 & $* * *$ & 0.6708 & 22.97 & $* * *$ & -0.0590 & -0.58 & & -0.1391 & -1.19 & \\
\hline Year dummies & Yes & & & Yes & & & Yes & & & Yes & & \\
\hline Adj. R square & $77.02 \%$ & & & $76.43 \%$ & & & $63.11 \%$ & & & $63.23 \%$ & & \\
\hline No. obs & 16,601 & & & 15,905 & & & 16,601 & & & 15,905 & & \\
\hline
\end{tabular}

Table 4 The conditional effect of distress risk on the relation between conservatism and loan quality

Panel A: Distress risk measured by low capital ratio

\begin{tabular}{|c|c|c|c|c|c|c|c|c|c|c|c|c|}
\hline & \multicolumn{6}{|c|}{ Dep Var $=N P L$ at $t+1$} & \multicolumn{6}{|c|}{ Dep $\operatorname{Var}=N C O$ at $t+1$} \\
\hline & \multicolumn{3}{|c|}{$\begin{array}{c}C O N=C-S c o r e \_L L P \\
\text { (1) }\end{array}$} & \multicolumn{2}{|c|}{$\begin{array}{c}C O N=L L P \_A S Y \\
\text { (2) }\end{array}$} & & \multicolumn{3}{|c|}{$\begin{array}{c}C O N=C-S c o r e \_L L P \\
\text { (3) }\end{array}$} & \multicolumn{3}{|c|}{$\begin{array}{c}C O N=L L P \_A S Y \\
\text { (4) }\end{array}$} \\
\hline & Coeff & $T$-stat & & Coeff & $T$-stat & & Coeff & $T$-stat & & Coeff & $T$-stat & \\
\hline Intercept & 0.0003 & 0.11 & & -0.0015 & -0.41 & & -0.0043 & -2.00 & & -0.0050 & -2.05 & \\
\hline CON & -0.0016 & -20.09 & $* * *$ & -0.0008 & -14.97 & $* * *$ & -0.0007 & -5.69 & $* *$ & -0.0004 & -3.95 & $* *$ \\
\hline LOWCAP & -0.0027 & -3.21 & $* *$ & 0.0006 & 0.58 & & -0.0003 & -0.33 & & -0.0010 & -2.33 & \\
\hline
\end{tabular}




\begin{tabular}{|c|c|c|c|c|c|c|c|c|c|c|c|c|}
\hline$C O N * L O W C A P$ & -0.0017 & -4.32 & $* *$ & -0.0006 & -3.61 & $* *$ & -0.0005 & -5.96 & $* * *$ & 0.0000 & -0.22 & \\
\hline$L Q$ & 0.6812 & 40.64 & $* * *$ & 0.6959 & 315.77 & $* * *$ & 0.5759 & 26.75 & $* * *$ & 0.5885 & 28.31 & $* * *$ \\
\hline$L Q^{*} L O W C A P$ & -0.0421 & -2.30 & & -0.0007 & -0.08 & & -0.0090 & -0.48 & & -0.0020 & -0.14 & \\
\hline$S I Z E^{*} L O W C A P$ & 0.0001 & 2.06 & & 0.0002 & 6.99 & $* * *$ & 0.0000 & 1.36 & & 0.0001 & 3.20 & $* *$ \\
\hline$A B S G A P^{*} L O W C A P$ & -0.0005 & -1.82 & & -0.0006 & -2.14 & & -0.0005 & -4.08 & $* *$ & -0.0004 & -5.44 & $* *$ \\
\hline$F E E^{*} L O W C A P$ & 0.0002 & 0.24 & & -0.0001 & -0.09 & & 0.0002 & 2.79 & $*$ & -0.0003 & -1.03 & \\
\hline$R O A V O L * L O W C A P$ & 0.1424 & 0.95 & & -0.0674 & -0.68 & & 0.0670 & 2.20 & & 0.0127 & 0.56 & \\
\hline$E F F^{*} L O W C A P$ & 0.0218 & 1.08 & & 0.0123 & 1.80 & & 0.0100 & 5.23 & $* *$ & 0.0063 & 1.29 & \\
\hline$E B L L P * L O W C A P$ & -0.1045 & -1.47 & & -0.0948 & -3.60 & $* *$ & -0.0027 & -0.45 & & -0.0108 & -0.92 & \\
\hline$L O A N * L O W C A P$ & 0.0006 & 0.19 & & -0.0007 & -0.28 & & -0.0025 & -5.27 & $* *$ & -0.0011 & -1.09 & \\
\hline$L G^{*} L O W C A P$ & 0.0001 & 0.18 & & 0.0000 & 0.01 & & 0.0002 & 1.84 & & 0.0001 & 2.67 & $*$ \\
\hline$C O M M{ }^{*} L O W C A P$ & 0.0025 & 1.08 & & -0.0054 & -1.46 & & 0.0032 & 5.27 & $* *$ & 0.0006 & 0.79 & \\
\hline$R E^{*} L O W C A P$ & -0.0003 & -0.12 & & -0.0017 & -0.76 & & 0.0021 & 5.29 & $* *$ & 0.0013 & 1.63 & \\
\hline$C O N S * L O W C A P$ & 0.0005 & 0.22 & & -0.0009 & -0.34 & & 0.0036 & 4.88 & $* *$ & 0.0012 & 1.07 & \\
\hline$L I Q U I D * L O W C A P$ & 0.0005 & 0.34 & & -0.0022 & -2.31 & & 0.0001 & 0.28 & & 0.0002 & 0.37 & \\
\hline$\triangle G D P^{*} L O W C A P$ & 0.0022 & 0.58 & & 0.0057 & 1.33 & & 0.0008 & 0.16 & & 0.0018 & 0.52 & \\
\hline$S I Z E$ & 0.0000 & 1.13 & & 0.0001 & 3.62 & $* *$ & 0.0001 & 6.15 & $* * *$ & 0.0001 & 7.92 & $* * *$ \\
\hline$A B S G A P$ & 0.0015 & 22.00 & $* * *$ & 0.0019 & 13.24 & $* * *$ & 0.0004 & 5.65 & $* *$ & 0.0005 & 7.25 & $* * *$ \\
\hline$F E E$ & -0.0007 & -1.88 & $*$ & -0.0017 & -4.40 & $* *$ & -0.0010 & -23.22 & $* * *$ & -0.0012 & -23.37 & $* * *$ \\
\hline ROAVOL & 0.2793 & 8.85 & $* * *$ & 0.2981 & 7.22 & $* * *$ & 0.1326 & 4.27 & $* *$ & 0.1322 & 5.66 & $* *$ \\
\hline$E F F$ & -0.0325 & -3.63 & $* *$ & -0.0271 & -4.14 & $* *$ & 0.0060 & 2.56 & $*$ & 0.0099 & 3.53 & $* *$ \\
\hline$E B L L P$ & 0.0998 & 6.08 & $* * *$ & 0.0959 & 5.60 & $* *$ & 0.0576 & 7.61 & $* * *$ & 0.0452 & 7.21 & $* * *$ \\
\hline$L O A N$ & 0.0033 & 9.16 & $* * *$ & 0.0039 & 9.08 & $* * *$ & 0.0019 & 4.51 & $* *$ & 0.0026 & 3.50 & $* *$ \\
\hline$L G$ & 0.0003 & 5.38 & $* *$ & 0.0003 & 3.22 & $* *$ & 0.0001 & 10.75 & $* * *$ & 0.0001 & 4.50 & $* *$ \\
\hline СOMM & -0.0028 & -9.41 & $* * *$ & -0.0014 & -2.06 & & -0.0009 & -5.16 & $* *$ & -0.0010 & -3.46 & $* *$ \\
\hline$R E$ & 0.0001 & 0.52 & & 0.0003 & 1.11 & & -0.0010 & -4.05 & $* *$ & -0.0012 & -2.80 & $*$ \\
\hline CONS & -0.0021 & -5.05 & $* *$ & -0.0029 & -4.78 & $* *$ & 0.0002 & 1.33 & & -0.0001 & -0.48 & \\
\hline$L I Q U I D$ & -0.0027 & -5.46 & $* *$ & -0.0024 & -4.02 & $* *$ & -0.0005 & -6.90 & $* * *$ & -0.0002 & -0.99 & \\
\hline$\triangle G D P$ & -0.0879 & -0.66 & & -0.1188 & -0.75 & & 0.0976 & 1.19 & & 0.0659 & 0.73 & \\
\hline Year dummies & Yes & & & Yes & & & Yes & & & Yes & & \\
\hline Adj. $R$ square & $76.42 \%$ & & & $75.43 \%$ & & & $62.46 \%$ & & & $61.43 \%$ & & \\
\hline
\end{tabular}


Panel B: Distress risk measured by return on equity (ROE)

\begin{tabular}{|c|c|c|c|c|c|c|c|c|c|c|c|c|}
\hline & \multicolumn{6}{|c|}{ Dep Var $=N P L$ at $t+1$} & \multicolumn{6}{|c|}{ Dep $\operatorname{Var}=N C O$ at $t+1$} \\
\hline & \multicolumn{3}{|c|}{$\begin{array}{c}C O N=C-S c o r e \_L L P \\
(1)\end{array}$} & \multicolumn{3}{|c|}{$C O N=\underset{L L P}{ }{ }_{(2)} A S Y$} & \multicolumn{3}{|c|}{$C O N=C-S c o r e \_L L P$} & \multicolumn{3}{|c|}{$C O N=L L P \_A S Y$} \\
\hline & Coeff & $T$-stat & & Coeff & $T$-stat & & Coeff & $T$-stat & & Coeff & $T$-stat & \\
\hline Intercept & 0.0007 & 0.27 & & 0.0002 & 0.07 & & -0.0037 & -1.70 & & 0.0002 & 0.07 & \\
\hline$C O N$ & -0.0017 & -50.38 & $* * *$ & -0.0025 & -21.07 & $* * *$ & -0.0006 & -6.24 & $* * *$ & -0.0013 & -6.33 & $* * *$ \\
\hline POORPERF & -0.0013 & -0.91 & & 0.0028 & 1.13 & & -0.0039 & -2.26 & & -0.0023 & -1.03 & \\
\hline$C O N * P O O R P E R F$ & -0.0009 & -4.94 & $* *$ & -0.0022 & -4.64 & $* *$ & -0.0006 & -1.94 & $*$ & 0.0002 & 1.14 & \\
\hline$L Q$ & 0.6625 & 33.61 & $* * *$ & 0.6679 & 98.78 & $* * *$ & 0.5688 & 70.05 & $* * *$ & 0.3374 & 42.80 & $* * *$ \\
\hline$L Q^{*} P O O R P E R F$ & -0.0006 & -0.03 & & -0.0330 & -3.07 & $*$ & -0.1130 & -2.34 & $*$ & -0.0319 & -0.56 & \\
\hline SIZE*POORPERF & 0.0001 & 1.84 & $*$ & 0.0001 & 1.38 & & 0.0002 & 3.16 & $*$ & 0.0001 & 1.58 & \\
\hline$A B S G A P * P O O R P E R F$ & 0.0014 & 4.91 & $* *$ & 0.0010 & 5.19 & $* *$ & 0.0006 & 1.59 & & 0.0004 & 1.08 & \\
\hline$F E E^{*} P O O R P E R F$ & 0.0002 & 0.16 & & 0.0007 & 0.83 & & -0.0020 & -3.69 & $* *$ & -0.0008 & -1.13 & \\
\hline ROAVOL *POORPERF & -0.2469 & -2.19 & $*$ & -0.2177 & -3.21 & $* *$ & 0.2041 & 2.05 & $*$ & -0.0791 & -3.22 & $* *$ \\
\hline$E F F^{*} P O O R P E R F$ & -0.0294 & -1.80 & $*$ & -0.0241 & -1.05 & & 0.0516 & 5.26 & $* *$ & 0.0347 & 4.55 & $* *$ \\
\hline$E B L L P * P O O R P E R F$ & 0.0022 & 0.09 & & -0.0236 & -2.79 & $*$ & 0.0507 & 2.00 & $*$ & -0.0043 & -0.27 & \\
\hline$L O A N^{*} P O O R P E R F$ & 0.0056 & 1.96 & $*$ & 0.0025 & 1.68 & & -0.0001 & -0.06 & & 0.0002 & 0.18 & \\
\hline$L G^{*} P O O R P E R F$ & -0.0001 & -1.02 & & -0.0001 & -0.96 & & 0.0000 & 0.98 & & 0.0000 & -0.34 & \\
\hline$C O M M * P O O R P E R F$ & -0.0083 & -8.63 & $* * *$ & -0.0074 & -7.81 & $* * *$ & -0.0020 & -2.24 & $*$ & -0.0027 & -5.93 & $* * *$ \\
\hline$R E^{*} P O O R P E R F$ & -0.0007 & -0.49 & & -0.0009 & -0.65 & & 0.0014 & 0.73 & & 0.0012 & 0.88 & \\
\hline CONS*POORPERF & -0.0041 & -1.65 & & -0.0060 & -3.36 & $* *$ & 0.0010 & 0.38 & & 0.0007 & 0.24 & \\
\hline$C A P^{*} P O O R P E R F$ & -0.0101 & -11.13 & $* * *$ & -0.0105 & -4.20 & $* *$ & -0.0026 & -2.49 & $*$ & 0.0001 & 0.05 & \\
\hline LIQUID*POORPERF & 0.0008 & 0.50 & & -0.0033 & -1.72 & & 0.0003 & 0.87 & & 0.0004 & 0.55 & \\
\hline$\triangle G D P * P O O R P E R F$ & -0.0177 & -1.09 & & -0.0104 & -0.46 & & -0.0046 & -0.49 & & -0.0099 & -1.27 & \\
\hline SIZE & 0.0000 & 1.45 & & 0.0002 & 10.96 & $* * *$ & 0.0001 & 3.35 & $* *$ & 0.0002 & 6.94 & $* * *$ \\
\hline$A B S G A P$ & 0.0011 & 6.11 & $* * *$ & 0.0013 & 7.48 & $* * *$ & 0.0003 & 4.46 & $* *$ & 0.0006 & 8.25 & $* * *$ \\
\hline$F E E$ & -0.0006 & -2.36 & $*$ & -0.0019 & -6.29 & $* * *$ & -0.0005 & -6.26 & $* * *$ & -0.0022 & -16.05 & $* * *$ \\
\hline ROAVOL & 0.3179 & 7.16 & $* * *$ & 0.3386 & 8.71 & $* * *$ & 0.0912 & 5.44 & $* *$ & 0.2437 & 6.02 & $* * *$ \\
\hline$E F F$ & -0.0230 & -2.28 & $*$ & -0.0146 & -2.21 & & 0.0009 & 1.10 & & 0.0233 & 6.13 & $* * *$ \\
\hline
\end{tabular}




\begin{tabular}{|c|c|c|c|c|c|c|c|c|c|c|c|c|}
\hline$E B L L P$ & 0.1010 & 5.16 & $* *$ & 0.0877 & 5.18 & $* *$ & 0.0745 & 20.31 & $* * *$ & 0.0569 & 8.01 & $* * *$ \\
\hline$L O A N$ & 0.0025 & 3.38 & $* *$ & 0.0031 & 2.94 & $*$ & 0.0016 & 3.22 & $* *$ & 0.0029 & 3.03 & $*$ \\
\hline$L G$ & 0.0004 & 6.48 & $* * *$ & 0.0003 & 5.63 & $* *$ & 0.0001 & 7.58 & $* * *$ & 0.0002 & 3.48 & $* *$ \\
\hline COMM & -0.0011 & -1.12 & & -0.0018 & -1.56 & & 0.0000 & -0.12 & & -0.0009 & -2.16 & \\
\hline$R E$ & 0.0003 & 0.96 & & -0.0001 & -0.12 & & -0.0008 & -2.87 & $*$ & -0.0015 & -2.63 & $*$ \\
\hline CONS & -0.0015 & -3.03 & $*$ & -0.0017 & -2.16 & & 0.0006 & 4.39 & $* *$ & 0.0003 & 1.04 & \\
\hline$C A P$ & 0.0010 & 0.62 & & -0.0025 & -3.71 & $* *$ & -0.0037 & -10.37 & $* * *$ & -0.0092 & -8.12 & $* * *$ \\
\hline LIQUID & -0.0024 & -3.75 & $* *$ & -0.0024 & -4.07 & $* *$ & -0.0004 & -5.68 & $* *$ & -0.0008 & -5.17 & $* *$ \\
\hline$\triangle G D P$ & -0.1230 & -1.09 & & -0.1605 & -1.18 & & 0.0937 & 1.23 & & -0.1969 & -1.43 & \\
\hline Year dummies & Yes & & & Yes & & & Yes & & & Yes & & \\
\hline Adj. R square & $76.55 \%$ & & & $76.20 \%$ & & & $63.18 \%$ & & & $51.27 \%$ & & \\
\hline No. obs & 18,358 & & & 17,514 & & & 18,358 & & & 17,514 & & \\
\hline
\end{tabular}

Table 5 Analysis of the relation between conservatism and loan quality depending on lending growth cycles

\begin{tabular}{|c|c|c|c|c|c|c|c|c|c|c|c|c|}
\hline & \multicolumn{5}{|c|}{ Dep Var=NPL at $t+1$} & & \multicolumn{5}{|c|}{ Dep Var $=N C O$ at $t+1$} & \\
\hline & \multicolumn{3}{|c|}{$\begin{array}{c}C O N=C-S c o r e \_L L P \\
\text { (1) }\end{array}$} & \multicolumn{2}{|c|}{$C O N=\underset{\text { (2) }}{L L P} P_{-} A S Y$} & & \multicolumn{2}{|c|}{$C O N=C-S c o r e \_L L P$} & & \multicolumn{3}{|c|}{$C O N=\underset{\text { (4) }}{L L P} P_{-} A S Y$} \\
\hline & Coeff & $T$-stat & & Coeff & $T$-stat & & Coeff & $T$-stat & & Coeff & $T$-stat & \\
\hline Intercept & -0.0006 & -0.22 & & 0.0014 & 0.37 & & -0.0045 & -1.98 & & -0.0070 & -2.94 & $*$ \\
\hline$C O N^{*} L O W$ & -0.0010 & -2.26 & $*$ & -0.0018 & -6.41 & $* * *$ & -0.0008 & -7.31 & $* * *$ & -0.0006 & -4.63 & $* *$ \\
\hline$C O N * M O D$ & -0.0001 & -0.47 & & -0.0004 & -1.68 & & -0.0002 & -3.84 & $* *$ & -0.0004 & -2.66 & $*$ \\
\hline$C O N * H I G H$ & -0.0047 & -22.56 & $* * *$ & -0.0066 & -19.86 & $* * *$ & -0.0014 & -6.12 & $* * *$ & -0.0017 & -5.09 & $* *$ \\
\hline$H I G H$ & 0.0094 & 3.18 & $*$ & 0.0071 & 1.66 & & 0.0068 & 2.53 & $*$ & 0.0077 & 3.06 & $*$ \\
\hline$M O D$ & 0.0028 & 0.85 & & 0.0053 & 1.15 & & -0.0019 & -0.99 & & -0.0028 & -1.60 & \\
\hline$L Q$ & 0.6777 & 36.80 & $* * *$ & 0.6699 & 107.34 & $* * *$ & 0.5803 & 31.20 & $* * *$ & 0.0621 & 4.97 & $* *$ \\
\hline SIZE & 0.0001 & 1.80 & & 0.0001 & 3.60 & $* *$ & 0.0001 & 5.66 & $* *$ & 0.4850 & 16.06 & $* * *$ \\
\hline$A B S G A P$ & 0.0013 & 41.89 & $* * *$ & 0.0014 & 13.40 & $* * *$ & 0.0004 & 4.47 & $* *$ & 0.0001 & 5.71 & $* *$ \\
\hline$F E E$ & -0.0004 & -1.13 & & -0.0013 & -3.63 & $* *$ & -0.0009 & -35.27 & $* * *$ & 0.0003 & 5.80 & $* *$ \\
\hline ROAVOL & 0.2749 & 6.44 & $* * *$ & 0.2800 & 6.75 & $* * *$ & 0.1402 & 4.60 & $* *$ & -0.0012 & -8.68 & $* * *$ \\
\hline$E F F$ & -0.0294 & -4.17 & $* *$ & -0.0267 & -5.25 & $* *$ & 0.0081 & 3.44 & $* *$ & 0.1079 & 4.65 & $* *$ \\
\hline$E B L L P$ & 0.0892 & 11.26 & $* * *$ & 0.0767 & 5.35 & $* *$ & 0.0537 & 6.83 & $* * *$ & 0.0150 & 9.55 & $* * *$ \\
\hline
\end{tabular}




\begin{tabular}{|c|c|c|c|c|c|c|c|c|c|c|c|c|}
\hline$L O A N$ & 0.0033 & 3.90 & $* *$ & 0.0032 & 3.77 & $* *$ & 0.0014 & 4.66 & $* *$ & 0.0532 & 10.75 & $* * *$ \\
\hline$L G$ & 0.0003 & 10.54 & $* * *$ & 0.0003 & 8.42 & $* * *$ & 0.0001 & 24.52 & $* * *$ & 0.0021 & 4.27 & $* *$ \\
\hline COMM & -0.0021 & -2.96 & $*$ & -0.0029 & -5.39 & $* *$ & -0.0003 & -7.16 & $* * *$ & 0.0001 & 4.15 & $* *$ \\
\hline$R E$ & 0.0003 & 0.72 & & 0.0002 & 0.35 & & -0.0005 & -4.07 & $* *$ & -0.0011 & -13.42 & $* * *$ \\
\hline CONS & -0.0025 & -3.84 & $* *$ & -0.0024 & -6.17 & $* * *$ & 0.0007 & 2.48 & $*$ & -0.0012 & -4.54 & $* *$ \\
\hline$C A P$ & -0.0013 & -1.72 & & -0.0038 & -2.98 & $*$ & -0.0038 & -5.65 & $* *$ & 0.0002 & 1.01 & \\
\hline$L I Q U I D$ & -0.0022 & -4.39 & $* *$ & -0.0028 & -4.28 & $* *$ & -0.0004 & -5.61 & $* *$ & -0.0055 & -6.71 & $* * *$ \\
\hline$\triangle G D P$ & -0.1131 & -0.95 & & -0.2174 & -1.33 & & 0.0910 & 1.07 & & -0.0001 & -0.60 & \\
\hline Year dummies & Yes & & & Yes & & & Yes & & & Yes & & \\
\hline Adj. $R$ square & $76.59 \%$ & & & $76.19 \%$ & & & $62.52 \%$ & & & $64.23 \%$ & & \\
\hline No. obs & 18,358 & & & 17,514 & & & 18,358 & & & 17,514 & & \\
\hline
\end{tabular}

Table 6 Analysis of the relation between conservatism and loan quality depending on bank size

Panel A: Using C-Score_LLP as CON measure

\begin{tabular}{|c|c|c|c|c|c|c|c|c|c|c|c|c|c|c|c|c|c|c|}
\hline & \multicolumn{12}{|c|}{ Dep Var $=N P L$ at $t+1$} & \multicolumn{6}{|c|}{ Dep Var $=N C O$ at $t+1$} \\
\hline & \multicolumn{18}{|c|}{$C O N=C$-Score_LLP } \\
\hline & \multicolumn{3}{|c|}{ Large } & \multicolumn{3}{|c|}{ Medium } & \multicolumn{3}{|c|}{ Small } & \multicolumn{3}{|c|}{ Large } & \multicolumn{3}{|c|}{ Medium } & \multicolumn{3}{|c|}{ Small } \\
\hline & Coeff & $T$-stat & & Coeff & $T$-stat & & Coeff & $T$-stat & & Coeff & $T$-stat & & Coeff & $T$-stat & & Coeff & $T$-stat & \\
\hline Intercept & -0.0043 & -2.55 & $*$ & -0.0015 & -0.86 & & -0.0078 & -1.38 & & -0.0004 & -1.50 & & -0.0017 & -2.18 & & -0.0050 & -9.09 & $* * *$ \\
\hline CON & -0.0013 & -9.53 & $* * *$ & -0.0025 & -13.68 & $* * *$ & -0.0017 & -10.74 & $* * *$ & -0.0006 & -6.79 & $* * *$ & -0.0008 & -5.04 & $* *$ & -0.0009 & -5.58 & $* *$ \\
\hline$L Q$ & 0.6763 & 15.25 & $* * *$ & 0.6465 & 43.62 & $* * *$ & 0.6630 & 42.15 & $* * *$ & 0.6114 & 65.40 & $* * *$ & 0.5785 & 18.91 & $* * *$ & 0.5124 & 28.78 & $* * *$ \\
\hline$S I Z E$ & 0.0001 & 1.41 & & -0.0001 & -0.59 & & -0.0005 & -2.41 & $*$ & 0.0001 & 3.03 & $*$ & 0.0001 & 1.91 & & 0.0000 & 0.15 & \\
\hline$A B S G A P$ & 0.0008 & 2.99 & $*$ & 0.0021 & 10.49 & $* * *$ & 0.0020 & 17.85 & $* * *$ & 0.0005 & 6.64 & $* * *$ & 0.0003 & 2.44 & $*$ & 0.0004 & 5.05 & $* *$ \\
\hline FEE & 0.0013 & 1.69 & & -0.0027 & -3.22 & $* *$ & -0.0018 & -4.08 & $* *$ & -0.0009 & -36.87 & $* * *$ & -0.0011 & -28.27 & $* * *$ & -0.0006 & -8.11 & $* * *$ \\
\hline ROAVOL & 0.3237 & 5.43 & $* *$ & 0.2660 & 4.55 & $* *$ & 0.2798 & 3.27 & $* *$ & 0.1578 & 5.68 & $* *$ & 0.1257 & 3.83 & $* *$ & 0.0872 & 2.05 & \\
\hline$E F F$ & -0.0336 & -2.55 & $*$ & -0.0146 & -2.19 & & -0.0326 & -4.44 & $* *$ & 0.0002 & 0.14 & & 0.0149 & 3.70 & $* *$ & 0.0049 & 1.55 & \\
\hline$E B L L P$ & 0.0857 & 2.37 & $*$ & 0.0505 & 2.31 & & 0.1200 & 6.84 & $* * *$ & 0.0665 & 15.80 & $* * *$ & 0.0338 & 3.95 & $* *$ & 0.0770 & 6.98 & $* * *$ \\
\hline
\end{tabular}




\begin{tabular}{|c|c|c|c|c|c|c|c|c|c|c|c|c|c|c|c|c|c|c|}
\hline$L O A N$ & 0.0010 & 0.53 & & -0.0010 & -0.82 & & 0.0086 & 2.53 & $*$ & 0.0032 & 4.60 & $* *$ & 0.0004 & 2.07 & & 0.0026 & 2.80 & $*$ \\
\hline$L G$ & 0.0003 & 2.76 & $*$ & 0.0004 & 4.23 & $* *$ & 0.0003 & 1.65 & & 0.0001 & 4.10 & $* *$ & 0.0002 & 7.37 & $* * *$ & 0.0001 & 2.41 & $*$ \\
\hline СОМM & -0.0001 & -0.02 & & -0.0010 & -1.54 & & -0.0028 & -1.03 & & -0.0024 & -5.27 & $* *$ & 0.0004 & 1.46 & & -0.0011 & -1.91 & \\
\hline$R E$ & 0.0027 & 1.20 & & 0.0025 & 3.04 & $*$ & -0.0029 & -1.15 & & -0.0019 & -5.33 & $* *$ & -0.0001 & -0.50 & & -0.0016 & -2.81 & $*$ \\
\hline CONS & 0.0014 & 0.52 & & 0.0012 & 1.29 & & -0.0052 & -1.56 & & -0.0016 & -7.21 & $* * *$ & 0.0006 & 1.12 & & 0.0006 & 1.21 & \\
\hline$C A P$ & -0.0137 & -2.58 & $*$ & 0.0117 & 7.42 & $* * *$ & -0.0064 & -1.15 & & -0.0075 & -5.95 & $* * *$ & -0.0022 & -2.16 & & -0.0018 & -1.07 & \\
\hline LIQUID & -0.0031 & -2.24 & & -0.0052 & -4.47 & $* *$ & 0.0018 & 1.67 & & -0.0001 & -1.37 & & -0.0012 & -4.90 & $* *$ & 0.0002 & 0.31 & \\
\hline$\triangle G D P$ & 0.1300 & 1.62 & & 0.1445 & 1.67 & & 0.3499 & 1.42 & & -0.0536 & -2.85 & $*$ & 0.0054 & 0.36 & & 0.1456 & 4.90 & $* *$ \\
\hline Year dummies & Yes & & & Yes & & & Yes & & & Yes & & & Yes & & & Yes & & \\
\hline Adj. $R$ square & $79.39 \%$ & & & $75.05 \%$ & & & $69.50 \%$ & & & $68.36 \%$ & & & $60.41 \%$ & & & $52.65 \%$ & & \\
\hline No. obs & 7,618 & & & 6,697 & & & 4,043 & & & 7,618 & & & 6,697 & & & 4,043 & & \\
\hline
\end{tabular}

The table reports the OLS regression results of the effect of conservatism on loan quality depending on the lending growth cycles. All variables are winsorized at 1 th and 99th percentiles. Please refer to the appendix for the definitions of these variables. Heteroskedasticity-robust t-statistics are in the parentheses.

Significance at the $10 \%, 5 \%$, and $1 \%$ level is indicated by $* * *$ and $* * *$ respectively. 
Panel B: Using LLP_ASY as CON measure

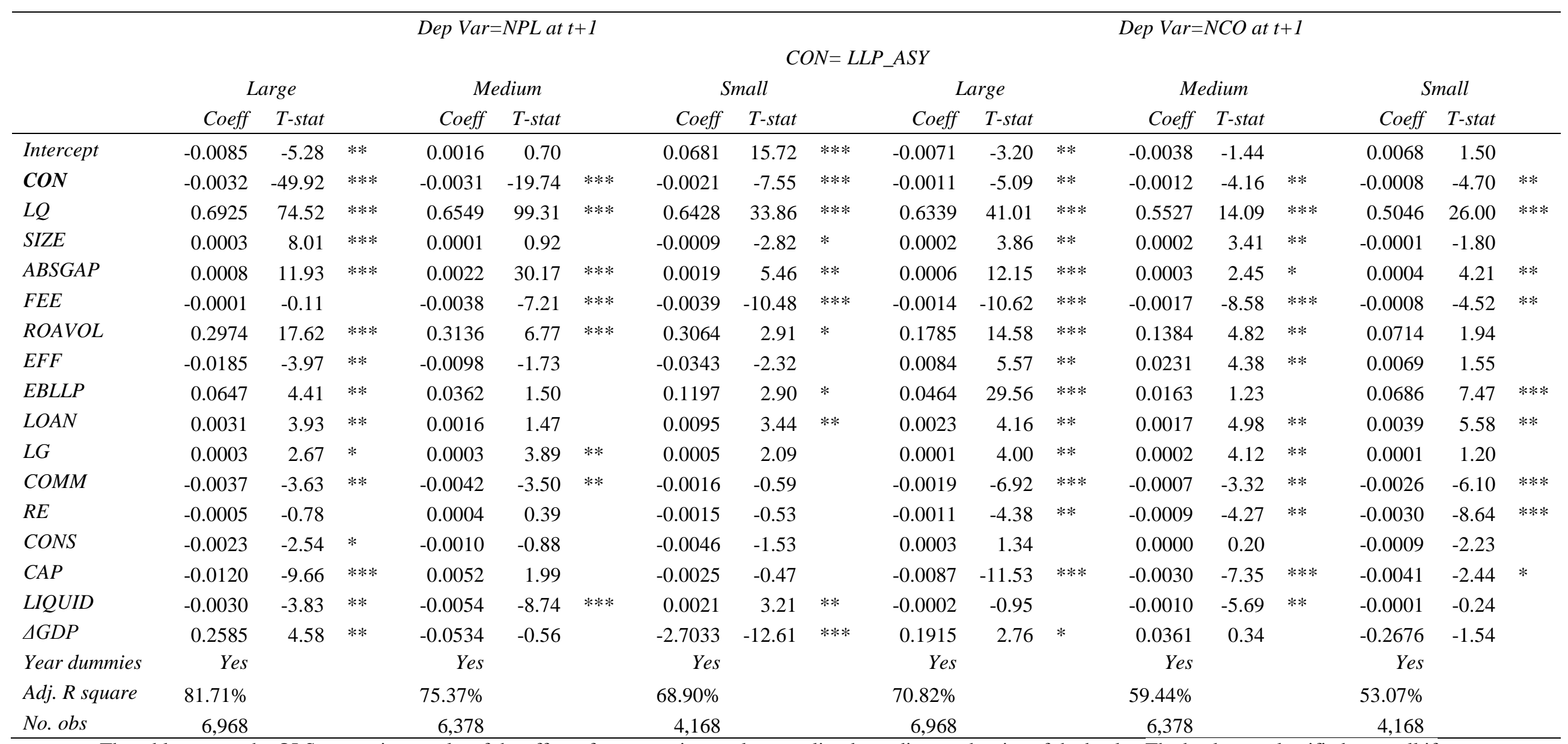

The table reports the OLS regression results of the effect of conservatism on loan quality depending on the size of the banks. The banks are classified as small if banks have total assets between $\$ 500$ million and $\$ 1$ billion, medium if banks have total assets between 1 billion and 3 billion, and large if banks have total assets more than 3 billion. All variables are winsorized at 1th and 99th percentiles. Please refer to the appendix for the definitions of these variables. Heteroskedasticityrobust t-statistics are in the parentheses. Significance at the $10 \%, 5 \%$, and $1 \%$ level is indicated by $* * *$ and $* * *$ respectively. 
Table 7 Change Specifications

\begin{tabular}{|c|c|c|c|c|c|c|c|c|c|c|c|c|}
\hline & \multicolumn{6}{|c|}{ Dep Var $=$ Change in NPL } & \multicolumn{6}{|c|}{ Dep Var= Change NCO } \\
\hline & \multicolumn{3}{|c|}{$\begin{array}{c}C O N=C-S c o r e \_L L P \\
(1)\end{array}$} & \multicolumn{3}{|c|}{$C O N=\underset{\text { (2) }}{L L P} P_{-} A S Y$} & \multicolumn{3}{|c|}{$\begin{array}{c}C O N=C-S c o r e \_L L P \\
(3)\end{array}$} & \multicolumn{3}{|c|}{$\begin{array}{c}C O N=L L P \_A S Y \\
(4)\end{array}$} \\
\hline & Coeff & T-stat & & Coeff & T-stat & & Coeff & $T$-stat & & Coeff & T-stat & \\
\hline Intercept & -0.0033 & -7.39 & $* * *$ & -0.0032 & -6.33 & $* * *$ & -0.0005 & -3.86 & $* *$ & -0.0004 & -3.43 & $* *$ \\
\hline$\triangle C O N$ & -0.0001 & -8.38 & $* * *$ & -0.0005 & -3.50 & $* *$ & 0.0000 & -4.51 & $* *$ & -0.0003 & -5.67 & $* *$ \\
\hline$\triangle L Q$ & -0.1422 & -20.16 & $* * *$ & -0.1731 & -18.69 & $* * *$ & -0.2285 & -10.79 & $* * *$ & -0.2544 & -8.89 & $* * *$ \\
\hline$\triangle S I Z E$ & 0.0026 & 6.11 & $* * *$ & 0.0031 & 9.34 & $* * *$ & 0.0009 & 4.33 & $* *$ & 0.0010 & 4.18 & $* *$ \\
\hline$\triangle A B S G A P$ & 0.0008 & 11.41 & $* * *$ & 0.0008 & 5.54 & $* *$ & 0.0001 & 1.45 & & 0.0001 & 1.54 & \\
\hline$\triangle F E E$ & -0.0006 & -0.78 & & -0.0008 & -1.76 & & -0.0010 & -4.10 & $* *$ & -0.0012 & -5.24 & $* *$ \\
\hline$\triangle R O A V O L$ & -0.0521 & -0.99 & & -0.0742 & -1.48 & & 0.0341 & 2.03 & & 0.0176 & 1.61 & \\
\hline$\triangle E F F$ & -0.0449 & -1.73 & & -0.0601 & -1.87 & & -0.0268 & -2.99 & $*$ & -0.0338 & -3.25 & $* *$ \\
\hline$\triangle E B L L P$ & 0.1292 & 17.71 & $* * *$ & 0.1339 & 9.21 & $* * *$ & 0.0451 & 6.59 & $* * *$ & 0.0620 & 6.52 & $* * *$ \\
\hline$\triangle L O A N$ & 0.0113 & 7.67 & $* * *$ & 0.0113 & 4.95 & $* *$ & 0.0056 & 3.24 & $* *$ & 0.0036 & 2.71 & $*$ \\
\hline$\Delta L G$ & 0.0001 & 2.05 & & 0.0001 & 2.82 & $*$ & 0.0000 & 0.73 & & 0.0000 & 1.57 & \\
\hline$\triangle C O M M$ & 0.0034 & 0.99 & & 0.0032 & 1.15 & & 0.0000 & 0.03 & & 0.0024 & 1.97 & \\
\hline$\triangle R E$ & 0.0024 & 1.56 & & 0.0010 & 1.78 & & -0.0005 & -0.47 & & 0.0012 & 1.55 & \\
\hline$\triangle C O N S$ & -0.0116 & -4.63 & $* *$ & -0.0135 & -5.63 & $* *$ & 0.0009 & 0.80 & & 0.0017 & 1.40 & \\
\hline$\triangle C A P$ & 0.0029 & 1.00 & & 0.0054 & 1.99 & & -0.0017 & -0.61 & & -0.0009 & -0.29 & \\
\hline$\triangle L I Q U I D$ & 0.0008 & 0.32 & & -0.0017 & -0.61 & & 0.0011 & 3.74 & $* *$ & 0.0005 & 2.96 & $*$ \\
\hline$\triangle G D P$ & -0.0920 & -2.97 & $*$ & -0.0329 & -0.97 & & -0.0424 & -4.31 & $* *$ & -0.0326 & -3.08 & $*$ \\
\hline $\begin{array}{l}\text { Year } \\
\text { dummies } \\
\text { Adj. } R\end{array}$ & Yes & & & Yes & & & Yes & & & Yes & & \\
\hline square & $31.24 \%$ & & & $31.21 \%$ & & & $24.08 \%$ & & & $24.00 \%$ & & \\
\hline No. obs & 16,249 & & & 15,493 & & & 16,249 & & & 15,493 & & \\
\hline
\end{tabular}

The table reports the baseline regression in first-differences where change in loan quality (change from $\mathrm{t}+1$ to $\mathrm{t}+2$ ) is regressed on change in $\mathrm{CON}$ and change in control variables (change from t to $\mathrm{t}+1$ ). All variables are winsorized at 1 th and 99 th percentiles. Please refer to the appendix for the definitions of these

variables. Heteroskedasticity-robust t-statistics are in the parentheses. Significance at the $10 \%, 5 \%$, and $1 \%$ level is indicated by $*, * *$ and $* * *$ respectively. 
Table 8 Using alternative proxies for monitoring effort (Replication of Table 2)

\begin{tabular}{|c|c|c|c|c|c|c|c|c|c|c|c|c|}
\hline & \multicolumn{6}{|c|}{ Dep var $=Z$-Score } & \multicolumn{6}{|c|}{ Dep var=adjSalExp } \\
\hline & \multicolumn{2}{|c|}{$\begin{array}{c}C O N=C-S c o r e \_L L P \\
(1)\end{array}$} & & \multicolumn{2}{|c|}{$C O N=L L P \_A S Y$} & & \multicolumn{2}{|c|}{$C O N=C-S c o r e \_L L P$} & & \multicolumn{3}{|c|}{$C O N=L L P \_A S Y$} \\
\hline & Coeff & T-stat & & Coeff & $T$-stat & & Coeff & $T$-stat & & Coeff & $T$-stat & \\
\hline Intercept & 0.2586 & 2.65 & $*$ & 0.5796 & 2.79 & $*$ & -0.0609 & -3.29 & $* * *$ & -0.0528 & -1.01 & \\
\hline CON & 0.2360 & 31.01 & $* * *$ & 0.2093 & 25.99 & $* * *$ & 0.0246 & 12.79 & $* * *$ & 0.0195 & 14.79 & $* * *$ \\
\hline SIZE & 0.0177 & 6.09 & $* * *$ & 0.0126 & 3.58 & $* *$ & -0.0001 & -0.15 & & -0.0002 & -5.99 & $* * *$ \\
\hline$A B S G A P$ & -0.1602 & -14.84 & $* * *$ & -0.1632 & -14.50 & $* * *$ & -0.0071 & -1.81 & $*$ & -0.0005 & -0.39 & \\
\hline$F E E$ & 0.4556 & 12.94 & $* * *$ & 0.3220 & 12.76 & $* * *$ & 0.0418 & 3.39 & $* * *$ & 0.0399 & 8.04 & $* * *$ \\
\hline ROAVOL & -171.8800 & -13.03 & $* * *$ & -170.1463 & -12.60 & $* * *$ & -5.0346 & -7.32 & $* * *$ & -5.0765 & -79.17 & $* * *$ \\
\hline$E F F$ & -8.6151 & -8.03 & $* * *$ & -7.6533 & -7.96 & $* * *$ & 0.0329 & 0.28 & & -0.0466 & -0.36 & \\
\hline$E B L L P$ & 38.4854 & 9.31 & $* * *$ & 36.1747 & 13.10 & $* * *$ & 0.5037 & 1.68 & $*$ & 1.0849 & 7.06 & $* * *$ \\
\hline$L O A N$ & 0.0537 & 0.62 & & 0.2228 & 2.28 & & 0.0873 & 4.20 & $* * *$ & 0.0633 & 7.46 & $* * *$ \\
\hline$L G$ & 0.0225 & 4.57 & $* *$ & 0.0191 & 3.22 & $* *$ & 0.0000 & 0.05 & & -0.0012 & -1.01 & \\
\hline COMM & -0.1972 & -2.34 & & -0.4377 & -8.43 & $* * *$ & -0.0371 & -1.54 & & -0.0196 & -3.03 & $*$ \\
\hline$R E$ & -0.2946 & -3.22 & $* *$ & -0.6417 & -6.48 & $* * *$ & -0.0654 & -3.11 & $* * *$ & -0.0503 & -6.90 & $* * *$ \\
\hline CONS & 0.7917 & 5.61 & $* *$ & 0.4206 & 2.85 & $*$ & -0.0927 & -3.28 & $* * *$ & -0.0572 & -6.06 & $* * *$ \\
\hline$C A P$ & 2.1486 & 12.94 & $* * *$ & 2.4551 & 28.10 & $* * *$ & 0.2732 & 6.60 & $* * *$ & 0.2543 & 9.41 & $* * *$ \\
\hline LIQUID & 0.2042 & 5.76 & $* *$ & 0.1178 & 2.39 & $*$ & 0.0355 & 2.64 & $* * *$ & 0.0278 & 10.88 & $* * *$ \\
\hline$\triangle G D P$ & 5.2561 & 3.49 & $* *$ & -4.1188 & -0.48 & & -0.3433 & -2.83 & $* * *$ & 0.5091 & 0.20 & \\
\hline $\begin{array}{l}\text { Year } \\
\text { dummies } \\
\text { Adj. R }\end{array}$ & Yes & & & Yes & & & Yes & & & Yes & & \\
\hline square & $16.67 \%$ & & & $14.95 \%$ & & & $16.88 \%$ & & & $16.82 \%$ & & \\
\hline No. obs & 18,358 & & & 17,514 & & & 18,358 & & & 17,514 & & \\
\hline
\end{tabular}

The table reports the OLS regression results of the effect of conservatism on loan quality using alternative dependent variables, Z-score and (negative) risk and industry-median adjusted salary expense. The Z-score measures the distance from insolvency. Because bank size and loan composition affect salary expense significantly, the median salary is calculated for each size tercile within the tercile based on the ratio of commercial loans to total assets for each quarter. All variables are winsorized at 1 th and 99 th percentiles. Heteroskedasticity-robust t-statistics are in the parentheses. Significance at the $10 \%, 5 \%$, and $1 \%$ level is indicated by $*, * *$ and $* * *$ respectively. 
Table 9 Corporate Governance Subsample Analysis

Panel A: Using C-Score_LLP as a dependent variable

Dep var $=$ NPL at $t+1$

Dep Var $=N C O$ at $t+1$

$C O N=C s c o r e \_L L P$

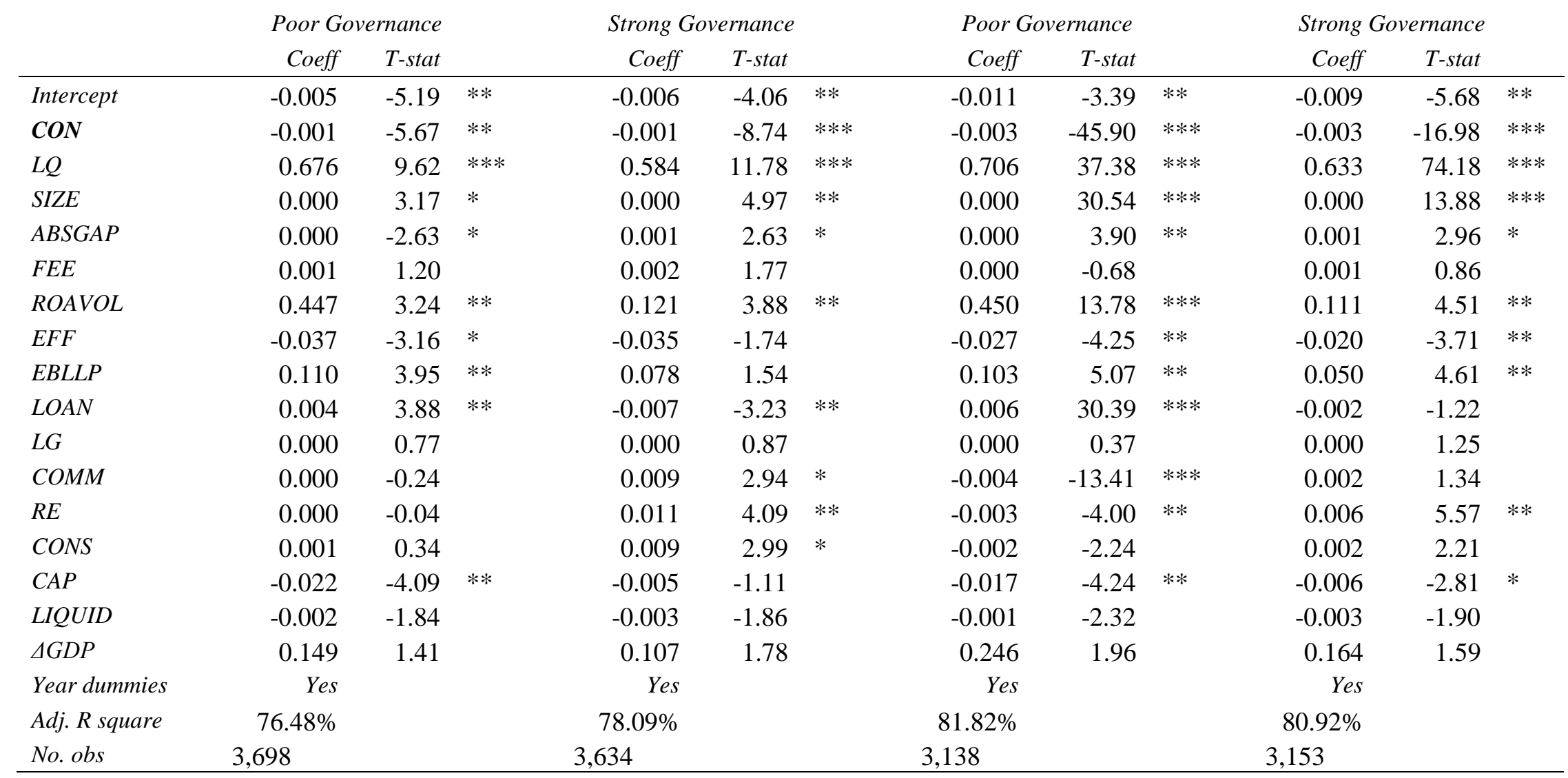


Panel B: Using LLP_ASY as a dependent variable

\begin{tabular}{|c|c|c|c|c|c|c|c|c|c|c|c|}
\hline \multicolumn{6}{|c|}{ Dep var $=N P L$ at $t+1$} & \multicolumn{6}{|c|}{ Dep Var $=$ NCO at $t+1$} \\
\hline \multicolumn{12}{|c|}{$C O N=L L P \_A S Y$} \\
\hline \multicolumn{3}{|c|}{ Poor Governance } & \multicolumn{3}{|c|}{ Strong Governance } & \multicolumn{3}{|c|}{ Poor Governance } & \multicolumn{3}{|c|}{ Strong Governance } \\
\hline Coeff & $T$-stat & & Coeff & $T$-stat & & Coeff & $T$-stat & & Coeff & $T-s t a t$ & \\
\hline 0.000 & 0.07 & & -0.001 & -2.06 & & -0.011 & -5.74 & $* *$ & -0.006 & -4.33 & $* *$ \\
\hline 0.000 & -5.77 & $* *$ & -0.001 & -5.98 & $* * *$ & -0.001 & -4.33 & $* *$ & -0.001 & -4.34 & $* *$ \\
\hline 0.635 & 51.09 & $* * *$ & 0.583 & 32.50 & $* * *$ & 0.628 & 28.62 & $* * *$ & 0.639 & 34.37 & $* * *$ \\
\hline 0.000 & 1.09 & & 0.000 & 3.18 & $*$ & 0.000 & 4.30 & $* *$ & 0.000 & 3.06 & $*$ \\
\hline 0.000 & 0.89 & & 0.001 & 5.40 & $* *$ & 0.000 & 3.07 & $*$ & 0.001 & 5.74 & $* *$ \\
\hline 0.000 & -1.29 & & -0.001 & -1.32 & & -0.001 & -6.15 & $* * *$ & -0.001 & -2.04 & \\
\hline 0.085 & 1.99 & & 0.085 & 7.01 & $* * *$ & 0.100 & 4.68 & $* *$ & 0.104 & 9.43 & $* * *$ \\
\hline-0.008 & -2.67 & $*$ & -0.003 & -0.59 & & 0.001 & 0.53 & & 0.006 & 1.23 & \\
\hline 0.093 & 6.98 & $* * *$ & 0.071 & 7.48 & $* * *$ & 0.073 & 7.72 & $* * *$ & 0.051 & 4.83 & $* *$ \\
\hline 0.003 & 9.19 & $* * *$ & 0.004 & 2.00 & & 0.003 & 5.63 & $* *$ & 0.003 & 2.04 & \\
\hline 0.000 & 1.78 & & 0.000 & 5.75 & $* *$ & 0.000 & 1.13 & & 0.000 & 3.66 & $* *$ \\
\hline-0.001 & -4.21 & $* *$ & -0.003 & -1.99 & & -0.002 & -7.74 & $* * *$ & -0.003 & -2.51 & $*$ \\
\hline-0.002 & -28.63 & $* * *$ & -0.002 & -1.75 & & -0.002 & -9.82 & $* * *$ & -0.002 & -1.85 & \\
\hline-0.002 & -2.58 & $*$ & -0.001 & -0.89 & & -0.002 & -5.09 & $* *$ & 0.001 & 2.14 & \\
\hline-0.006 & -2.83 & $*$ & -0.008 & -3.11 & $*$ & -0.007 & -7.76 & $* * *$ & -0.007 & -3.58 & $* *$ \\
\hline 0.000 & -2.25 & & 0.000 & -1.78 & & 0.000 & -1.42 & & 0.000 & -1.44 & \\
\hline-0.037 & -2.26 & & -0.043 & -2.54 & $*$ & 0.376 & 6.40 & $* * *$ & 0.147 & 2.98 & $*$ \\
\hline Yes & & & Yes & & & Yes & & & Yes & & \\
\hline $68.44 \%$ & & & $70.13 \%$ & & & $69.91 \%$ & & & $74.01 \%$ & & \\
\hline 3,698 & & & 3,634 & & & 3,138 & & & 3,153 & & \\
\hline
\end{tabular}

The table reports the OLS regression results of the effect of conservatism on loan quality depending on corporate governance. I divide the sample into weak and strong governance subsamples and repeat the regression analysis on these two subsamples seapartely. I use Gompers, Ishii, and Metrick (2003)'s $G$-score as a summary (inverse) measure of the strength of firms' corporate governance. Firms whose $G$-score equals or exceeds the median for the full sample are classified as "weak governance", and the remainder are placed in the "strong governance" subsample. All variables are winsorized at 1th and 99th percentiles. Please refer to the appendix for the definitions of these variables. Heteroskedasticity-robust t-statistics are in the parentheses. Significance at the $10 \%, 5 \%$, and $1 \%$ level is indicated by $* * *$ and $* * *$ respectively. 